\title{
Microbial sulfur transformations in sediments from Subglacial Lake Whillans
}

\author{
Alicia M. Purcell ${ }^{1}$, Jill A. Mikucki ${ }^{1}{ }^{*}$, Amanda M. Achberger $^{2}$, Irina A. Alekhina ${ }^{3}$, Carlo Barbante ${ }^{4}$, \\ Brent C. Christner ${ }^{2}$, Dhritiman Ghosh ${ }^{1}$, Alexander B. Michaud ${ }^{5}$, Andrew C. Mitchell ${ }^{6}$, John C. Priscu ${ }^{5}$, \\ Reed Scherer ${ }^{7}$, Mark L. Skidmore ${ }^{8}$, Trista J. Vick-Majors ${ }^{5}$ and the WISSARD Science Team \\ ${ }^{1}$ Department of Microbiology, University of Tennessee, Knoxville, TN, USA \\ ${ }^{2}$ Department of Biological Sciences, Louisiana State University, Baton Rouge, LA, USA \\ ${ }^{3}$ Climate and Environmental Research Laboratory, Arctic and Antarctic Research Institute, St. Petersburg, Russia \\ ${ }^{4}$ Institute for the Dynamics of Environmental Processes - Consiglio Nazionale delle Ricerche and Department of Environmental Sciences, Informatics and \\ Statistics, Ca' Foscari University of Venice, Venice, Italy \\ ${ }^{5}$ Department of Land Resources and Environmental Sciences, Montana State University, Bozeman, MT, USA \\ ${ }^{6}$ Geography and Earth Sciences, Aberystwyth University, Ceredigion, UK \\ ${ }^{7}$ Department of Geological and Environmental Sciences, Northern Illinois University, DeKalb, IL, USA \\ ${ }^{8}$ Department of Earth Sciences, Montana State University, Bozeman, MT, USA
}

\section{Edited by:}

Andreas Teske, University of North

Carolina at Chapel Hill, USA

\section{Reviewed by:}

Aharon Oren, The Hebrew University

of Jerusalem, Israel

John B. Kirkpatrick, University of

Rhode Island, USA

${ }^{*}$ Correspondence:

Jill A. Mikucki, Department of Microbiology, University of

Tennessee, M409 Walters Life Sciences, 1414 West Cumberland Avenue, Knoxville, TN 37996, USA e-mail: jmikucki@utk.edu
Diverse microbial assemblages inhabit subglacial aquatic environments. While few of these environments have been sampled, data reveal that subglacial organisms gain energy for growth from reduced minerals containing nitrogen, iron, and sulfur. Here we investigate the role of microbially mediated sulfur transformations in sediments from Subglacial Lake Whillans (SLW), Antarctica, by examining key genes involved in dissimilatory sulfur oxidation and reduction. The presence of sulfur transformation genes throughout the top $34 \mathrm{~cm}$ of SLW sediments changes with depth. SLW surficial sediments were dominated by genes related to known sulfur-oxidizing chemoautotrophs. Sequences encoding the adenosine-5'-phosphosulfate (APS) reductase gene, involved in both dissimilatory sulfate reduction and sulfur oxidation, were present in all samples and clustered into 16 distinct operational taxonomic units. The majority of APS reductase sequences $(74 \%)$ clustered with known sulfur oxidizers including those within the "Sideroxydans" and Thiobacillus genera. Reverse-acting dissimilatory sulfite reductase (rDSR) and 16S rRNA gene sequences further support dominance of "Sideroxydans" and Thiobacillus phylotypes in the top $2 \mathrm{~cm}$ of SLW sediments. The SLW microbial community has the genetic potential for sulfate reduction which is supported by experimentally measured low rates $\left(1.4 \mathrm{pmol} \mathrm{cm}^{-3} \mathrm{~d}^{-1}\right)$ of biologically mediated sulfate reduction and the presence of APS reductase and DSR gene sequences related to Desulfobacteraceae and Desulfotomaculum. Our results also infer the presence of sulfur oxidation, which can be a significant energetic pathway for chemosynthetic biosynthesis in SLW sediments. The water in SLW ultimately flows into the Ross Sea where intermediates from subglacial sulfur transformations can influence the flux of solutes to the Southern Ocean.

Keywords: Antarctic subglacial aquatic environments, geomicrobiology, chemosynthesis, sulfur oxidation, sulfate reduction

\section{INTRODUCTION}

Subglacial aquatic environments exist beneath the Antarctic Ice Sheet as lakes, streams, marine brines, and water-saturated sediments (Priscu etal., 2008; Fricker and Scambos, 2009; Mikucki et al., 2009; Skidmore, 2011; Wright and Siegert, 2012). Recently, the Whillans Ice Stream Subglacial Access Research Drilling (WISSARD) project directly sampled water and sediment from Subglacial Lake Whillans (SLW), one of the 379 identified Antarctic subglacial lakes (Wright and Siegert, 2012).

Abbreviations: SLW, Subglacial Lake Whillans; WIS, Whillans Ice Stream; SOP, sulfur-oxidizing prokaryotes; SRP, sulfate-reducing prokaryotes; APS, adenosine$5^{\prime}$-phosphosulfate reductase; DSR, dissimilatory sulfite reductase; rDSR, reverse dissimilatory sulfite reductase.
Initial analyses of samples collected from SLW show the presence of an active community of diverse heterotrophic and autotrophic microorganisms in the water column and surficial sediments (Christner et al., 2014). Substrates for subglacial growth are primarily derived from minerals and organic matter in the underlying sediments (Tranter et al., 2005). Recent evidence for the presence of sulfur cycling microorganisms in Antarctic subglacial environments (Christner et al., 2006, 2014; Lanoil et al., 2009; Mikucki et al., 2009), implies that sulfur transformations may provide chemical energy for growth in these cold, dark ecosystems. Measurements of metabolic substrate concentrations, enrichment cultures, molecular surveys, sulfur and oxygen isotopic composition, and microcosm experiments 
have been used to infer the presence of sulfate reduction and sulfide oxidation beneath Arctic and Alpine glaciers (Skidmore et al., 2000, 2005; Bottrell and Tranter, 2002; Wadham et al., 2004; Montross et al., 2013). Similarly in Antarctic subglacial systems, sulfide oxidation has been inferred as an important microbial process from 16S rRNA gene sequence data (Mikucki and Priscu, 2007; Lanoil et al., 2009) and geochemical measurements (Skidmore et al., 2010; Wadham et al., 2010). However, there have been few studies on functional gene diversity in Antarctic subglacial systems.

Sulfur is required for cellular components, such as the amino acids cysteine and methionine; however, some microorganisms utilize sulfur compounds in dissimilatory, energy-yielding metabolic processes. The sulfur-oxidizing prokaryotes (SOP) are metabolically and phylogenetically diverse (Friedrich et al., 2001, 2005), and can fix $\mathrm{CO}_{2}$ utilizing a variety of electron acceptors including $\mathrm{O}_{2}, \mathrm{NO}_{3}{ }^{-}, \mathrm{Mn}^{3+/ 4+}$, and $\mathrm{Fe}^{3+}$ (Mattes et al., 2013). Sulfate-reducing prokaryotes (SRP) respire organic material for energy and use sulfate as an electron acceptor when oxygen is absent (Jørgensen, 1982; Jørgensen and Postgate, 1982). Reduced sulfur compounds generated by sulfate reduction can provide energy for the SOP component of the community, although a larger fraction of reduced sulfur for microbial oxidation may come from mineral sources. This may be important subglacially, where the grinding of glacial ice over bedrock would expose reactive mineral surfaces (Anderson, 2007). Sulfate reduction is widely recognized as an important process in other dark and cold environments including anaerobic marine sediments, where it contributes to greater than $50 \%$ of total organic carbon oxidation globally (Canfield etal., 1993; Thullner et al., 2009; Bowles et al., 2014). The linkage of the sulfur and carbon cycles in Antarctic subglacial environments has not been well characterized. Here we aimed to survey the potential role of sulfur transforming communities in SLW sediments.

We measured rates of sulfate reduction and analyzed the presence and diversity of three dissimilatory sulfur cycling genes (APS, DSR, and rDSR) in sediments collected from SLW. APS reductase is a conserved enzyme among both SRP and SOP (Meyer and Kuever, 2007c) and the alpha subunit of APS reductase, aprA, is a common marker for both metabolic groups (Meyer and Kuever, 2007c). DSR is found in all SRP and catalyzes the final energyyielding step of sulfite reduction to hydrogen sulfide (Wagner et al., 1998; Zverlov et al., 2005; Rabus et al., 2006). A homolog of DSR, reverse-acting DSR (rDSR), is a marker for some sulfur-storing and oxidizing members of the phyla Chlorobi and Proteobacteria and is thought to be involved in the oxidation of intracellular stored elemental sulfur compounds (Pott and Dahl, 1998; Loy et al., 2008, 2009).

Our results show that prokaryotes in SLW sediments mediate sulfur transformations and that the potential for sulfur oxidation by chemosynthetic bacteria is present in SLW sediments. Microbial sulfur metabolism can influence mineral dissolution and precipitation indirectly via production of acidic metabolic byproducts, or directly via electron transfer (Ehrlich, 1996; Banfield et al., 1999). Because water beneath the WIS drains into the surrounding ocean (Carter and Fricker, 2012), microbial transformations of sulfur beneath the WIS could influence biogeochemical cycling upon release of metabolic byproducts into the Ross Sea and possibly the Southern Ocean.

\section{MATERIALS AND METHODS SITE DESCRIPTION AND SAMPLE COLLECTION}

Subglacial Lake Whillans is located beneath the downstream portion of the WIS (S 84.237 ${ }^{\circ}$, W $153.614^{\circ}$; Christianson et al., 2012), ca. $100 \mathrm{~km}$ from the grounding zone, where the ice sheet transitions into the Ross Ice Shelf (Figure 1). SLW is a shallow $(\sim 2.2 \mathrm{~m}$ deep; Tulaczyk et al., 2014) lake located in what appears to be a large wetland along the Siple Coast of West Antarctica (Priscu et al., 2010; Fricker et al., 2011). SLW is considered an 'active' lake as it drains and refills on a sub-decadal time scale discharging water towards the Ross Sea (Fricker et al., 2007; Carter and Fricker, 2012; Siegfried et al., 2014). In January 2013, the WISSARD Project ${ }^{1}$ used hot water drilling to penetrate $801 \pm 1 \mathrm{~m}$ of glacial ice to access SLW. Details of drilling operations are described elsewhere (Tulaczyk et al., 2014). A clean access protocol (Priscu et al., 2013) was followed to maintain both sample integrity and environmental stewardship. Briefly, drilling water was passed through two filtration units $(2.0$ and $0.2 \mu \mathrm{m})$ to remove large particulates and microbial cells. Water was then subjected to ultraviolet irradiation of $185 \mathrm{~nm}$ for organic matter destruction and germicidal $254 \mathrm{~nm}$. Finally, drilling water was pressurized and heated to $90^{\circ} \mathrm{C}$ and used to melt an access borehole. Instruments were cleaned with 3\% hydrogen peroxide and cables and hoses were deployed through a UV collar during deployment down the borehole (Priscu et al., 2013; Christner et al., 2014).

Sediments from SLW were collected using a gravity driven multi-corer (Uwitec) built for recovery of sediment cores and water from the sediment-water interface. The multi-corer successfully recovered $\sim 40 \mathrm{~cm}$ of sediment and $20 \mathrm{~cm}$ of basal water in most deployments (Tulaczyk et al., 2014). Sediment cores analyzed in this study were collected from the second (identified as core 'MC-2B') and third multicore deployment (core 'MC3C'; Tulaczyk et al., 2014). Cores contained conspicuous bubbles when brought to the surface, suggesting possible degassing during core retrieval. Ice above the lake moved $\sim 5 \mathrm{~cm}$ during the second and third multi-core casts, thus samples may represent overlapping locations (Tulaczyk et al., 2014). Approximately two thirds of the sediments from MC-3C slipped out of the core tube, leaving the top $\sim 16 \mathrm{~cm}$ of sediment, which was structurally undisturbed. Cores were vertically extruded and serially sectioned using a core stand and cutter (Uwitec) in a Class 100 laminar flow hood. Sediments were sampled from three depth intervals in each core. MC-2B was sampled at depths of 0-4, 48 , and 28-34 cm and MC-3C was sampled at depths of 2.0-3.5, $3.5-8.0$, and $8-16 \mathrm{~cm}$ (Table 1). Samples are referred to by core name with the depth in subscript throughout this manuscript, for example MC- $2 \mathrm{~B}_{(0-4 \mathrm{~cm})}$. Sediments for metabolic activity experiments were processed on site. Samples for nucleic acid extraction were stored in sterile whirl-pak (Nasco) bags at $-10^{\circ} \mathrm{C}$ at the field site and then shipped to the University of Tennessee in the dark at $-20^{\circ} \mathrm{C}$.

${ }^{1}$ www.wissard.org 


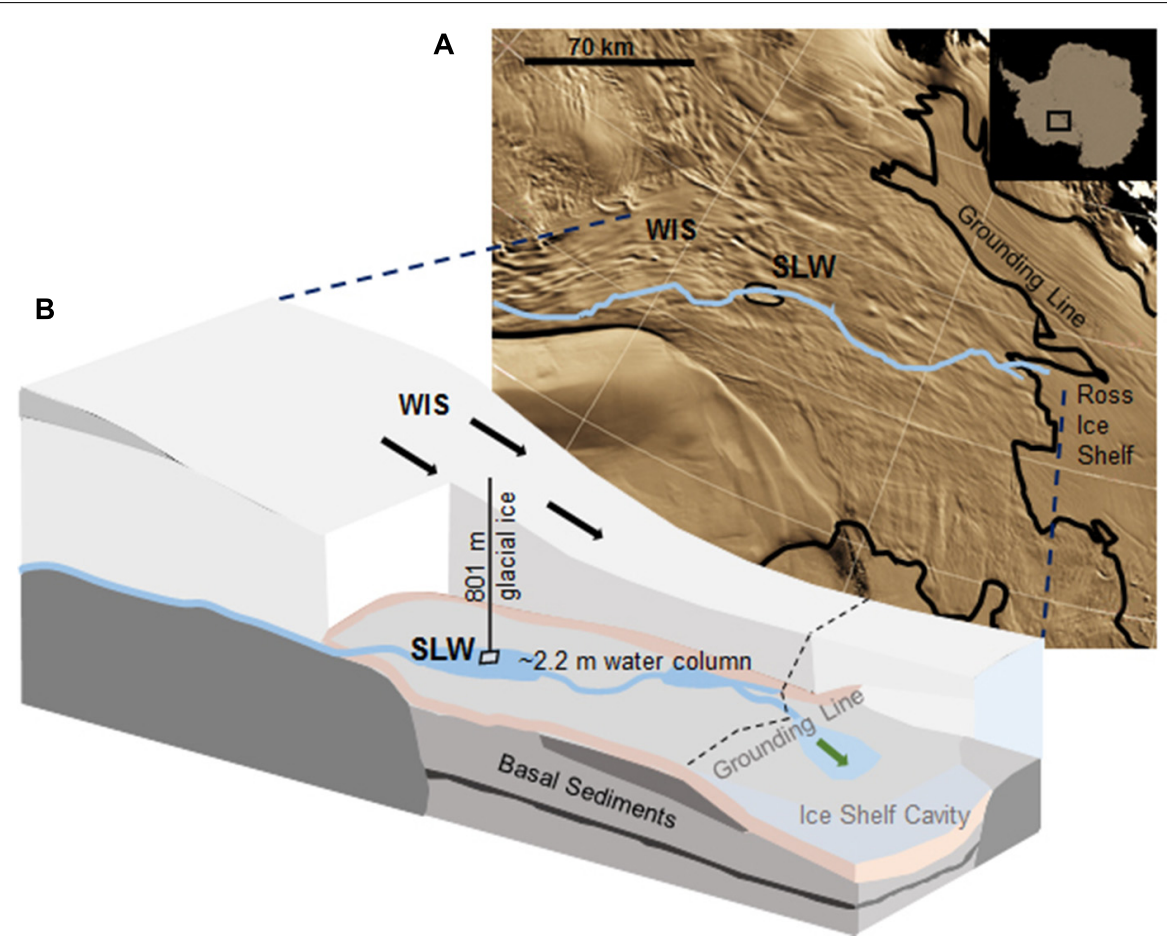

FIGURE 1 | Location of Subglacial Lake Whillans (SLW) and schematic of the Whillans Ice Stream (WIS). (A) Satellite image of the Siple Coast with SLW labeled (after Fricker and Scambos, 2009); the blue line indicates the proposed subglacial water flow path toward the grounding line (Carter and Fricker, 2012). Background satellite image from MODIS Mosaic of Antarctica (Haran etal., 2005). (B) Cross- sectional cartoon of the WIS indicating the borehole created through $801 \mathrm{~m}$ of ice. Sediment cores were collected through $\sim 2.2 \mathrm{~m}$ of water. Black arrows indicate the direction of ice movement; green arrow indicates predicted dispersal of subglacial water into the marine cavity beneath the Ross Ice Shelf. Cross-sectional cartoon of the WIS adapted from Fricker etal. (2011).

Table 1 | Subglacial Lake Whillans sediment samples used in this study, gene amplifications, sulfate reduction rates (SRR), and quantitative-PCR gene quantification.

\begin{tabular}{|c|c|c|c|c|c|c|c|c|c|c|c|}
\hline \multicolumn{2}{|c|}{ Sample } & \multicolumn{4}{|c|}{ Gene } & \multicolumn{2}{|c|}{$\begin{array}{l}\text { Sulfate Reduction Rates } \\
\left(\mathrm{SRR} ; \mathrm{pmol} \mathrm{cm}^{-3} \mathrm{~d}^{-1}\right)^{\mathrm{b}}\end{array}$} & \multicolumn{4}{|c|}{$\begin{array}{l}\text { Gene quantification (copies } \mathbf{g}^{-1} \text { wet } \\
\text { sediment) }\end{array}$} \\
\hline Core & $\begin{array}{l}\text { Depth } \\
\text { (cm) }\end{array}$ & $\begin{array}{l}\text { aprA } \\
\text { (384 bp) }\end{array}$ & $\begin{array}{l}d s r A B \\
(1.9 \mathrm{~kb})\end{array}$ & $\begin{array}{l}d s r A \\
(221 \mathrm{bp})\end{array}$ & $\begin{array}{l}r d s r A B^{\mathrm{a}} \\
(1.9 \mathrm{~kb})\end{array}$ & $\begin{array}{l}\text { Without } \\
\text { formate }\end{array}$ & $\begin{array}{l}\text { With } \\
\text { formate }\end{array}$ & $\begin{array}{l}\text { Bacterial } \\
16 S \text { rRNA }\end{array}$ & $\begin{array}{l}\text { Archaeal } \\
\text { 16S rRNA }\end{array}$ & aprA & $\begin{array}{l}\% \text { aprA of } \\
16 S \text { rRNA }\end{array}$ \\
\hline MC-2B & $0-4$ & + & - & + & + & $0.42^{* *}$ & $0.41 * *$ & $3.9 \times 10^{6}$ & $2.4 \times 10^{6}$ & $9.12 \times 10^{5}$ & $14.5 / 23.6$ \\
\hline MC-3C & $2-3.5$ & + & - & + & + & $1.67^{*}$ & $1.29^{*}$ & $8.5 \times 10^{6}$ & $4.4 \times 10^{6}$ & $9.58 \times 10^{5}$ & $7.4 / 11.3$ \\
\hline MC-3C & $3.5-8$ & + & + & + & + & $1.20^{*}$ & $1.84^{* *}$ & $2.2 \times 10^{5}$ & $9.0 \times 10^{5}$ & $2.47 \times 10^{4}$ & $2.2 / 11.1$ \\
\hline MC-3C & $8-16$ & + & + & + & - & ND & ND & $2.0 \times 10^{4}$ & $4.0 \times 10^{5}$ & $3.67 \times 10^{3}$ & $0.9 / 18$ \\
\hline
\end{tabular}

Gene amplifications from SLW sediments: "+ " indicates positive amplification. "- " indicates no amplification.

${ }^{a}$ At least one of the primer combinations amplified (Table 2).

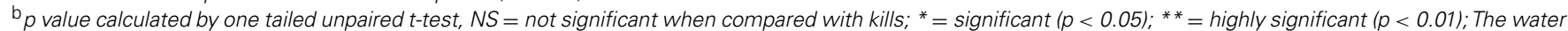
column was NS. ND = Not Determined.

${ }^{\mathrm{C}}$ First number is \% aprA with respect to total prokaryote $16 S$ rRNA gene copies and second is with respect to total bacterial 16S rRNA from Q-PCR quantification.

\section{${ }^{35} \mathrm{~S}$-SULFATE INCUBATION EXPERIMENTS}

Biologically mediated sulfate reduction was measured using the passive extraction method (Ulrich et al., 1997) following incubation with ${ }^{35} \mathrm{SO}_{4}{ }^{2-}$ tracer. Sediment $(\sim 5 \mathrm{~g})$ from selected depths (Table 1) was aseptically transferred using a sterile spatula into pre-weighed, pre-combusted, $\mathrm{N}_{2}$-gassed serum vials. 
These depths were selected because they corresponded to the lowest reduction potential in both cores (at $\sim 3.5 \mathrm{~cm}$; Mitchell and Mikucki, unpublished data). MC- $2 \mathrm{~B}_{(0-4 \mathrm{~cm})}$ corresponded to the surficial sediments selected for extensive biogeochemical characterization (i.e., Christner et al., 2014). Sulfate reduction experiments were also conducted on SLW lake water $(5 \mathrm{ml})$. All solutions used in this experiment were $\mathrm{N}_{2}$-flushed. Sediment slurries were made with the addition of one $\mathrm{ml}$ sterile DNA-free water (Fisher) to minimize issues caused by potential isotope diffusion within the sediments. Small test tubes containing $2.5 \mathrm{ml}$ of $10 \%$ zinc acetate (sulfide traps) flushed with $\mathrm{N}_{2}$ gas were added to each serum vial. Blank serum vials containing sterile water were incubated along with all samples to correct for possible background transfer of the radiolabel to the traps. $2.75 \mu \mathrm{Ci}{ }^{35} \mathrm{~S}_{-} \mathrm{SO}_{4}{ }^{2-}$ (specific activity $\sim 1490 \mathrm{Ci} / \mathrm{mmol}$ ) was added with a sterile syringe. This injection added $25 \mathrm{nM}$ of sulfate to the porewater. Each sediment sample depth included three live and three killed controls whereas bulk SLW water included four live and four killed samples (kills $=2 \%$ paraformaldehyde, final concentration). Because two organic carbon atoms are oxidized for every sulfate ion reduced, formate $(50 \mathrm{mM}$, final concentration) was added to a parallel set of sediment samples to ensure that that organic carbon was present at saturating levels during the incubation period. Samples were incubated at $1-2^{\circ} \mathrm{C}$ for 9 days. Experiments were terminated with the addition of $6 \mathrm{M} \mathrm{HCl}(8 \mathrm{ml})$ and $1 \mathrm{M} \mathrm{CrCl}_{2}$ in $0.5 \mathrm{M} \mathrm{HCl}(8 \mathrm{ml})$. Vials were mixed at $125 \mathrm{RPM}$ for $48 \mathrm{~h}$ to ensure all total reactive inorganic $\mathrm{S}$ (TRIS) was liberated as $\mathrm{H}_{2} \mathrm{~S}$ and precipitated in the zinc traps. This passive extraction method has been shown to efficiently extract TRIS as $\mathrm{FeS}, \mathrm{FeS}_{2}$, and $\mathrm{S}^{2-}$ but has low efficiency for the extraction of $S^{\circ}$ thus it may underestimate total sulfate reduction (Ulrich et al., 1997). Zinc traps were then removed and the contents added to scintillation cocktail (Cytoscint ES). Activity was measured using standard liquid scintillation spectrometry in the Crary Lab at McMurdo Station. Sulfate reduction rates (SRR; pmol SO${ }_{4}^{-2} \mathrm{~cm}^{-3} \mathrm{~d}^{-1}$ ) were computed according to the equation (Fossing and Jørgensen, 1989)

$$
S R R=\frac{a}{A+a} * \frac{\left[\mathrm{SO}_{4}^{2-}\right]}{t} * 1.06
$$

Where $a$ is the radioactivity $\left(\mathrm{dpm}_{\text {live }}-\mathrm{dpm}_{\text {kills }}\right)$ in the TRIS fraction, $A$ is the radioactivity (dpm) added to the sample as ${ }^{35} \mathrm{~S}$ $\mathrm{SO}_{4}{ }^{2-}$. $\left[\mathrm{SO}_{4}{ }^{2-}\right]$ is the concentration of sulfate $\left(\mathrm{pmol} \mathrm{cm}{ }^{-3}\right)$ in the sample at time zero, $t$ is the incubation time (days), and 1.06 is a correction factor for enzymatic isotope discrimination. Sulfate reduction rates presented represent the mean $( \pm S D)$ of three replicates. Sulfate was present in the water column $(0.56 \mathrm{mM})$ and surficial sediments (0.62 mM; Christner et al., 2014). Density, porosity, and sulfate concentrations in sediment porewater for the experimental depths were based on values collected from the replicate cores, $\mathrm{MC}-2 \mathrm{~A}$ (density and porosity) and $\mathrm{MC}-3 \mathrm{~B}$ (sulfate concentrations) obtained during the second and third multi-corer casts, respectively (Michaud and Priscu, in preparation). Porosity and density in core MC-2A were measured as described by Riedinger et al. (2010). Given that we imposed anaerobic conditions during these experiments and the exact oxygen levels in situ remain unknown, all rates should be considered as potential.

\section{MICROBIAL CELL ENUMERATION}

Cells were enumerated from one sediment sample collected from the exterior of an instrument that penetrated into the sediments to a depth no greater than $20 \mathrm{~cm}$; therefore, this sample was not obtained from a discrete depth. Cells were extracted from bulk sediments as follows. Slurries were prepared in triplicate by homogenizing sediments ( $2-4 \mathrm{~g}$ ) with $1 \mathrm{X}$ PBS buffer (final ratio $1: 2$ ). Slurries were fixed with paraformaldehyde ( $2 \%$ final concentration) for $\sim 16 \mathrm{~h}$, then methanol and a $1 \%$ Tween 80 solution were added ( $10 \%$ final concentration) to detach cells from sediments; this chemical extraction step was modified from Kallmeyer et al. (2008). Slurries were vortexed at medium-high speed at $4^{\circ} \mathrm{C}$ for $30 \mathrm{~min}$. then centrifuged at a low speed, $50 \times g$, to settle out the coarser sediment particles (at least $1 \mathrm{~h}$ at $4^{\circ} \mathrm{C}$ ). The supernatant (2-3 mls), including the cells and the finest sediment fraction was then filtered onto a $0.2 \mu \mathrm{m}$ polycarbonate filter and stained with 25X SYBR Gold nucleic acid stain (Invitrogen ${ }^{\mathrm{TM}}$ ) for $15 \mathrm{~min}$ (Ball and Virginia, 2014). Filters were rinsed with $1 \mathrm{ml}$ of $0.2 \mu \mathrm{m}$ filtered nanopure water and enumerated using epi-fluorescence microscopy (Leica DM5500B with an excitation filter set BP 480/40). A procedural blank using the solutions was processed alongside the sample replicates and quantified to assess any potential contamination. Three $\mathrm{ml}$ of autoclaved $0.2 \mu \mathrm{m}$ filtered nanopure water was passed through the filtration towers and filtered before each sample replicate and quantified and subtracted from total sample counts. Our extraction method required $\sim 6$ g of sediment, which limited our ability to analyze each depth in our study. A quantitative-PCR (Q-PCR) approach was used instead to estimate abundance despite known caveats, including PCR inhibitors in environmental samples, and DNA extraction and primer biases (Smith and Osborn, 2009).

\section{DNA EXTRACTION AND PCR AMPLIFICATION}

DNA was extracted in triplicate from $0.3-0.4 \mathrm{~g}$ of sediment in a class II type A2 clean hood (LabConco model \#3460001) using the FastDNA $^{\text {TM }}$ SPIN Kit (MP Biomedicals) according to the manufacturer's protocol. Eluent containing DNA from each replicate was pooled. Kit solutions were extracted simultaneously as a control for methodological contamination. A fragment (384-396 bp) of the alpha subunit of aprA was amplified using the forward primer AprA-1-FW and reverse primer AprA-5-RV (Meyer and Kuever, 2007c). A short fragment (221 bp) of the alpha subunit of $d s r A$ was amplified using forward primer DSR1F+ and reverse primer DSR-R (Kondo et al., 2004). DSR alpha and beta subunits $(d s r A B)$ were amplified $(1.9 \mathrm{~kb})$ using forward primer DSR1F and reverse primer DSR4R (Wagner et al., 1998). Reverse dissimilatory reductase alpha and beta subunits $(r d s r A B)$ were amplified with all published forward and reverse $r d s r A B$ primer combinations (Loy et al., 2009; Lenk et al., 2011). All primer sequences are listed in Table 2. REDTaq $^{\circledR}$ ReadyMix $^{\mathrm{TM}}$ PCR Reaction Mix (Sigma Aldrich) was used with each primer combinations according to the manufacturer's protocol. PCR reactions contained $25 \mu \mathrm{l}$ RedTaq, $4 \mu$ l of template ( $<15$ ng DNA ul ${ }^{-1}$ ), $1 \mu$ l of each forward and reverse primer (final primer concentration $200 \mathrm{nM}$ ), and $19 \mu \mathrm{l}$ of nuclease-free water for a final volume of $50 \mu \mathrm{l}$. Amplification of aprA was initiated at $94^{\circ} \mathrm{C}$ for $2 \mathrm{~min}$, followed by 40 cycles (Green-Saxena etal., 2012) of $1 \mathrm{~min} 94^{\circ} \mathrm{C}$ denaturation; $1 \mathrm{~min}$ 
Table 2 | DNA oligonucleotide primers used in this study.

\begin{tabular}{|c|c|c|}
\hline Primer and use & Sequence $\left(5^{\prime}-3^{\prime}\right)$ & Reference \\
\hline \multicolumn{3}{|c|}{ PCR Amplification and cloning } \\
\hline \multirow[t]{2}{*}{ AprA-1-FW Forward } & TGGCAGATCATGATYMAYGG & Meyer and \\
\hline & & Kuever (2007c) \\
\hline \multirow[t]{2}{*}{ AprA-5-RV Reverse } & GCGCCAACYGGRCCRTA & Meyer and \\
\hline & & Kuever (2007c) \\
\hline \multirow[t]{2}{*}{ DSR1F+ Forward } & ACSCACTGGAAGCACGGCGG & Kondo et al. \\
\hline & & (2004) \\
\hline \multirow[t]{2}{*}{ DSR-R Reverse } & GTGGMRCCGTGCAKRTTGG & Kondo et al. \\
\hline & & $(2004)$ \\
\hline \multirow[t]{2}{*}{ DSR1 Forward } & ACSCACTGGAAGCACG & Wagner et al. \\
\hline & & (1998) \\
\hline \multirow[t]{2}{*}{ DSR4 Reverse } & GTGTAGCAGTTACCGCA & Wagner et al. \\
\hline & & (1998) \\
\hline rDSR1Fa & AARGGNTAYTGGAARG & Loy et al. (2009) \\
\hline rDSR1Fb & TTYGGNTAYTGGAARG & Loy et al. (2009) \\
\hline rDSR1Fc & ATGGGNTAYTGGAARG & Loy et al. (2009) \\
\hline rDSR4Ra & CCRAARCAIGCNCCRCA & Loy et al. (2009) \\
\hline rDSR4Rb & GGRWARCAIGCNCCRCA & Loy et al. (2009) \\
\hline rDSRA240F & GGNTAYTGGAARGGNGG & Lenk et al. (2011 \\
\hline rDSR808R & CCDCCNACCCADATNGC & Lenk et al. (2011 \\
\hline \multicolumn{3}{|l|}{ Sequencing } \\
\hline T3 & \multicolumn{2}{|l|}{ ATTAACCCTCACTAAAGGGA } \\
\hline T7 & \multicolumn{2}{|l|}{ TAATACGACTCACTATAGGG } \\
\hline \multicolumn{3}{|l|}{ Q-PCR } \\
\hline \multirow[t]{2}{*}{ Bac340 Forward } & TCCTACGGGAGGCAGCAGT & Nadkarni et al. \\
\hline & & $(2002)$ \\
\hline \multirow[t]{2}{*}{ Bac515 Reverse } & CGTATTACCGCGGCTGCTGGCAC & Nadkarni et al. \\
\hline & & $(2002)$ \\
\hline \multirow[t]{3}{*}{ Arc915 Forward } & AGGAATTGGCGGGGGAGCAC & Takai and \\
\hline & & Horikoshi \\
\hline & & $(2000)$ \\
\hline Arc1059 Reverse & GCCATGCACCWCCTCT & Yu et al. (2005) \\
\hline
\end{tabular}

$48^{\circ} \mathrm{C}$ annealing; and $1 \mathrm{~min} 72^{\circ} \mathrm{C}$ extension, then a final elongation of $7 \mathrm{~min}$ at $72^{\circ} \mathrm{C}$. Amplification of aprA was increased to 43 cycles for core $\mathrm{MC}-2 \mathrm{~B}_{(4-8 \mathrm{~cm})}$ because no amplification was observed after 40 cycles. Annealing temperature was increased to $57^{\circ} \mathrm{C}$ and repeated for 41 cycles for $d s r A$ amplification. $d s r A B$ and $r d s r A B$ amplification was performed as described for $a p r A$, but included 42 cycles, 2 min extension, with a final elongation of 7 min Extracts $(4 \mu \mathrm{l})$ from kit blanks and sterile water reagent blanks were processed for PCR controls for all amplifications. No amplification products were detected in the controls without template or in extraction kit blanks.

\section{QUANTITATIVE PCR}

Gene copy abundances of bacterial and archaeal 16S rRNA genes and $a p r A$ were measured in triplicate (technical replicates) using an $\mathrm{iQ}^{\mathrm{TM}} 5$ Multicolor Real-Time PCR Detection System (Bio Rad). Standards for bacterial and archaeal 16S rRNA genes were constructed using DNA extracted from pure cultures of Escherichia coli and Methanocaldococcus jannaschii, respectively. 16S rRNA genes were amplified then gel purified using Wizard PCR clean up (Promega), and cloned using the TOPO ${ }^{\circledR}$ TA cloning kit (Life Technologies) with One Shot ${ }^{\circledR}$ TOP10 Chemically Competent E. coli and the $\mathrm{pCR}^{\mathrm{TM}} 4$ cloning vector. Plasmids were purified using the PureYield ${ }^{\text {TM }}$ Plasmid Miniprep System (Promega). Starting gene copy abundances in extracted plasmid were calculated according to Ritalahti et al. (2006). Plasmids were serially diluted to concentrations of $1 \times 10^{1}$ to $1 \times 10^{9}$ copies $\mu 1^{-1}$. aprA gene standards were made using plasmids extracted from an aprA clone from this study and were diluted to concentrations of $1 \times 10^{1}$ to $1 \times 10^{7}$ copies $\mu \mathrm{l}^{-1}$. A two-step protocol described by Lloyd et al. (2011) was used to quantify amplification under the following conditions: $95^{\circ} \mathrm{C}$ for $5 \mathrm{~min}$ and $40 \mathrm{cycles}$ of $95^{\circ} \mathrm{C}$ for $1 \mathrm{~min}$ and $60^{\circ} \mathrm{C}$ for $30 \mathrm{sec}$ Melting curves were performed at $0.5^{\circ} \mathrm{C}$ steps from $55^{\circ} \mathrm{C}$ to $95^{\circ} \mathrm{C}$ and analyzed after each quantification to check for primer dimer formation and amplification specificity. All samples were quantified on the same Q-PCR run and samples from the same DNA extraction were used to quantify all genes. $16 \mathrm{~S}$ rRNA primer targets and coverage were checked in silico using TestPrime 1.0 application (Klindworth et al., 2012) using the SILVA SSU r119 RefNR database (Quast et al., 2013²). 16S rRNA gene primer sets in this study (Table 2) cover $73 \%$ of the domain Bacteria (0\% Archaea) and $73 \%$ of the domain Archaea (0\% Bacteria). Primers from this study (Table 2), have successfully been used for aprA quantification in Peru margin sediment samples (Blazejak and Schippers, 2011). All reactions had a final volume of 25 and $12.5 \mu$ l of QuantiFast SYBR Green PCR mastermix (Qiagen, Valencia, CA), and $2 \mu \mathrm{l}$ of template. Primer concentrations were $80 \mathrm{nM}$ for bacterial and archaeal 16S rRNA genes (Lloyd et al., 2011) and $200 \mathrm{nM}$ for aprA. All standards were only thawed once and run in triplicate. Threshold cycles were averaged to make a standard curve. Starting quantities were calculated from a log-linear standard curve $\left(\mathrm{R}^{2}\right.$ value $\geq 0.98)$. The instrument detection limit for archaeal $16 \mathrm{~S}$ rRNA genes were $1 \times 10^{3}$ copies $\mu 1^{-1}$, bacterial $16 \mathrm{~S}$ rRNA genes were $1 \times 10^{2}$ copies $\mu l^{-1}$, and aprA was $1 \times 10^{1}$ copies $\mu l^{-1}$. Controls included DNA extraction blanks and Q-PCR reagents without template. Controls amplified more than 2 threshold cycles later than samples or fell below the quantification limit for each gene.

\section{CLONE LIBRARY CONSTRUCTION}

Amplicons of $a p r A, d s r A, d s r A B$, and $r d s r A B$ genes were purified by gel extraction using the Wizard ${ }^{\circledR}$ SV Gel and PCR Clean-Up System (Promega) following the manufacturer's protocol. Products from 7 primer sets for $r d s r A B$ were pooled; for all other genes, only one primer set was used (Table 2). Clone libraries were constructed using $\mathrm{TOPO}^{\circledR} \mathrm{TA}$ cloning kit (Invitrogen ${ }^{\mathrm{TM}}$ ) with One Shot ${ }^{\circledR}$ TOP10 Chemically Competent E. coli and the $\mathrm{pCR}^{\mathrm{TM}_{4}}$ cloning vector. Approximately 50 colonies were randomly picked after growth on LB agar plates with kanamycin and cultured in LB. Plasmids were extracted using the PureYield ${ }^{\mathrm{TM}}$ Plasmid Miniprep

${ }^{2}$ http://www.arb-silva.de 
System (Promega) following the manufacturer's protocol. Sanger sequencing was performed on the extracted plasmids using the T3 and T7 primers (Table 2). ABI Big-Dye v3.1 cycle sequencing mix was used for reactions run on an ABI 3130 analyzer (Applied Biosystems) at the University of Tennessee, Knoxville Molecular Biology Resource Facility and the Clemson University Genomics Institute.

\section{PHYLOGENETIC AND DIVERSITY ANALYSES}

Nucleotide sequences were imported into BioEdit version 7.2.3 $\left(\right.$ Hall, 1999 $\left.{ }^{3}\right)$. Vector sequence was removed, and nucleotide sequences were checked for possible chimeric artifacts using the Bellerophon program (Huber et al., 2004) or manually by BLASTn alignment analysis (Antony etal., 2010; Nilsson etal., 2010). Nucleotide sequences were translated into amino acid sequences and aligned using ClustalW (Larkin et al., 2007) in BioEdit (Hall, 1999). Numerous functional gene diversity studies of environmental samples studies use an amino acid sequence identity cut off 90-97\% to describe distinct operational taxonomic units (OTUs; Loy et al., 2009; Lenk et al., 2011; Leloup et al., 2009). Here we define OTUs for $a p r A, d s r A$, and $r d s r A$ sequences as clusters of sequences having an amino acid sequence identity of $90 \%$ or greater (Loy et al., 2009; Lenk et al., 2011). All functional gene sequences in this study were grouped into OTUs using the BlastClust tool $^{4}$. Only the alpha subunit portion of the $1.9 \mathrm{~kb} d s r A B$ and $r d s r A B$ (255 amino acids) was used for cluster analyses. Amino acid sequences were searched against the NR database in NCBI using BLASTp $^{5}$.

Phylogenetic analysis included aligning aprA sequences from reference strains and sequences of highest amino acid identity to cultured and uncultured aprA sequences in the NR database. aprA OTUs were then functionally classified as SRP or SOP based on lineages defined by Meyer and Kuever (2007a). These lineage designations are supported by amino acid indels that are unique to the lineages (Meyer and Kuever, 2007a,b). Sequences that did not fall within either the SRP or SOP aprA lineages were referred to as sequences of uncertain function. After designating aprA sequences into OTUs, one representative sequence from each OTU was selected for tree construction. A neighbor-joining tree was constructed using MEGA version 6 (Tamura et al., 2013) and

\footnotetext{
${ }^{3}$ http://www.mbio.ncsu.edu/bioedit/bioedit.html

${ }^{4} \mathrm{http}: / /$ toolkit.tuebingen.mpg.de/blastclust

${ }^{5}$ http://blast.be-md.ncbi.nlm.nih.gov/Blast.cgi
}

Jones-Thornton-Taylor (JTT) substitution model and a bootstrap analysis of 1000 replicates.

Statistical tests (Table 3) were calculated to evaluate aprA diversity including, Shannon-Weaver diversity index $\left(H^{\prime}\right)$ and Simpson's index $(D)$. Sampling coverage was evaluated using the Chaol richness estimator, Good's coverage, and rarefaction. Good's coverage $(C)$ was calculated using the equation $C=1-$ $\left(n_{i} / N\right)$, where $n_{i}$ is the number of single unique clones, and $N$ is the total number of clones in the library (Good, 1953; Singleton et al., 2001). Simpson's and Shannon-Weaver diversity indices, and Chaol richness estimator were calculated using standard equations in Hill et al. (2003). Chaol richness estimator was calculated to estimate the OTU abundance expected in each clone library using standard equations in Hill et al. (2003). Rarefaction curves were generated to estimate the thoroughness of sequencing. Curves were generated using $\mathrm{R}$ version 2.15.0 ( $\mathrm{R}$ Development Core Team, 2008) and a modified $\operatorname{script}^{6}$ to evaluate our clone library size.

\section{NUCLEOTIDE SEQUENCE ACCESSION NUMBERS}

Nucleotide sequences of the $\operatorname{apr} A, d s r A$, and $r d s r A$ genes from this study were deposited in GenBank under the accession numbers KM589857-KM590347.

\section{RESULTS}

\section{ACTIVITY OF SULFATE-REDUCING PROKARYOTES}

${ }^{35} \mathrm{SO}_{4}{ }^{2-}$ amended incubation experiments of sediment slurries indicated that SRR were statistically significant in all three of the SLW sediments samples tested, albeit at low rates (average $=1.4 \mathrm{pmol} \mathrm{cm} \mathrm{cm}^{-3} \mathrm{~d}^{-1} \pm 0.60$; Table 1; Figure 2). There was no significant stimulation in sulfide production with the addition of formate (Table 1; Figure 2). Activity in SLW water column samples was not detected (i.e., live samples were not statistically greater than kills). The highest rates of sulfate reduction were measured in unamended samples from $\mathrm{MC}-3 \mathrm{C}_{(2-3.5 \mathrm{~cm})}$ (avg $\left.=1.7 \mathrm{pmol} \mathrm{cm} \mathrm{cm}^{-3} \mathrm{~d}^{-1} \pm 0.54\right)$ and formate amended MC$3 \mathrm{C}_{(3.5-8 \mathrm{~cm})}\left(\right.$ avg $=1.8 \mathrm{pmol} \mathrm{cm}{ }^{-3} \mathrm{~d}^{-1} \pm 0.43$; Table 1; Figure 2). Lower rates were measured in $\left.\mathrm{MC}-2 \mathrm{~B}_{(0-4} \mathrm{cm}\right)($ avg $=0.4 \mathrm{pmol}$ $\mathrm{cm}^{-3} \mathrm{~d}^{-1} \pm 0.04$; Table 1; Figure 2). MC-3C was stored at $4^{\circ} \mathrm{C}$ in its core tube for $\sim 24 \mathrm{~h}$ while $\mathrm{MC}-2 \mathrm{~B}$ was processed; however, the sediments collected from MC-2B were likely exposed to oxygen during processing. Unlike the MC-3C samples for SRR, MC-2B sediments were not immediately transferred to $\mathrm{N}_{2}$-gassed

${ }^{6}$ http://www.jennajacobs.org/R/rarefaction.html

Table 3 | Estimates of aprA diversity, richness, and clone library coverage in SLW sediments.

\begin{tabular}{|c|c|c|c|c|c|c|c|}
\hline Sediment sample & All & $\mathrm{MC}-2 \mathrm{~B}_{(0-4 \mathrm{~cm})}$ & 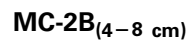 & $\left.M C-2 B_{(28-34} \mathrm{cm}\right)$ & $\left.M C-3 C_{(2-3.5} \mathrm{cm}\right)$ & $M C-3 C_{(3.5-8 \mathrm{~cm})}$ & $\left.M C-3 C_{(8-16} \mathrm{cm}\right)$ \\
\hline Total \# clones & 275 & 45 & 28 & 39 & 45 & 40 & 39 \\
\hline Total \# operational taxonomic unit (OTUs) & 16 & 6 & 3 & 8 & 4 & 6 & 8 \\
\hline Good's coverage & 0.98 & 0.93 & 0.96 & 0.92 & 0.98 & 0.93 & 0.92 \\
\hline Simpson's index (D) & 0.40 & 0.61 & 0.5 & 0.24 & 0.68 & 0.45 & 0.16 \\
\hline Shannon-Weaver index $\left(\mathrm{H}^{\prime}\right)$ & 1.50 & 0.83 & 0.77 & 1.62 & 0.63 & 1.09 & 1.82 \\
\hline Chao1 richness estimator & 34 & 11 & 3 & 13 & 5 & 6 & 8 \\
\hline
\end{tabular}




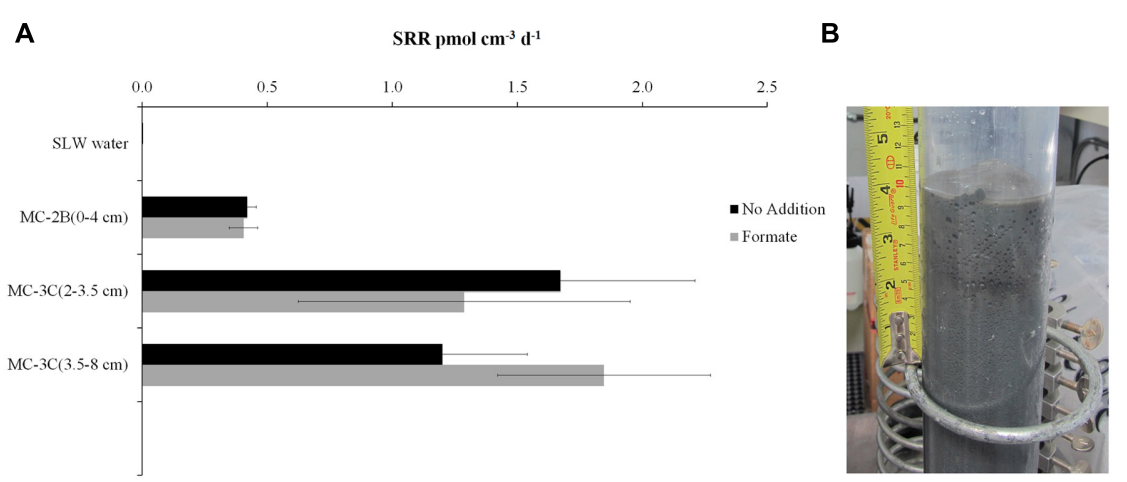

FIGURE 2 | Sulfate reduction rates (SRR) in SLW sediment samples. (A) SRR for killed controls was subtracted from each sample replicate. Black bars represent sediment incubations with no carbon addition; Gray bars represent sediment incubations with $50 \mathrm{mM}$ formate addition ( \pm SD of triplicates). (B) Image of SLW sediment core MC-2B.

serum vials due to logistical constraints. Thus, variations in rates between depths could have been affected by limitations of our field laboratory.

\section{QUANTIFICATION OF BIOMASS AND TOTAL 16S rRNA AND aprA GENES}

DNA-containing cell abundance in the sediment sample quantified by microscopy was $2.0 \times 10^{5} \pm 5.1 \times 10^{4}$ cells $^{-1}$ wet sediment. The microbial cells quantified had morphologies visibly distinct from auto fluorescent mineral grains. Copies of bacterial and archaeal 16S rRNA genes were equally abundant in the surficial sediments, and copy numbers of all three genes decreased with depth (Table 1; Figure 3). Abundance of total 16S rRNA genes decreased from $6.3 \times 10^{6}$ copies $\mathrm{g}^{-1}$ in $\mathrm{MC}-2 \mathrm{~B}_{(0-4 \mathrm{~cm})}$ and $1.3 \times 10^{7}$ copies $\mathrm{g}^{-1}$ in $\mathrm{MC}-3 \mathrm{C}_{(2-3.5 \mathrm{~cm})}$ (the two top depths) to $1.5 \times 10^{6}$ copies $\mathrm{g}^{-1}$ in MC-2B $(28-34 \mathrm{~cm})$ and $4.2 \times 10^{5}$ copies $^{-1}$ in $\mathrm{MC}-3 \mathrm{C}_{(8-16 \mathrm{~cm})}$ (the lower depths; Table 1; Figure 3). Gene copy numbers of aprA decreased from $9.1 \times 10^{5}$ copies $\mathrm{g}^{-1}$ in $\mathrm{MC}-2 \mathrm{~B}_{(0-4 \mathrm{~cm})}$ and $9.6 \times 10^{5}$ copies $\mathrm{g}^{-1}$ in $\mathrm{MC}-3 \mathrm{C}_{(2-3.5 \mathrm{~cm})}$ to $8.4 \times 10^{3}$ copies $\mathrm{g}^{-1}$ in $\mathrm{MC}-2 \mathrm{~B}_{(28-34 \mathrm{~cm})}$ and $3.7 \times 10^{3}$ copies $\mathrm{g}^{-1}$ in $\mathrm{MC}-3 \mathrm{C}_{(8-16 \mathrm{~cm})}$ (Table 1; Figure 3).

\section{aprA GENE}

Amplification of aprA was detected in all samples (Table 1) and a total of 275 aprA clones were sequenced from SLW sediments. Both SRP and SOP functional types were present in SLW. The SLW sequences formed 16 distinct OTUs (Table 4). aprA sequences related to SOP comprised $74 \%$ of total aprA sequences (Table 4). The most abundant aprA OTU, 1A, represented $61 \%$ of the total sequences and was found in all samples analyzed. OTU1A sequences were affiliated with SOP lineage I, and were 97-94\% identical to the aprA found in the Betaproteobacterium, "Sideroxydans lithotrophicus” ES-1 (Table 4; Figure 4). Other SOP-related sequences (OTUs $3 \mathrm{~A}$ and $13 \mathrm{~A}$; combined $6 \%$ of total sequences) fell within SOP lineage II and were 95-92\% related to Thiobacillus spp., including Thiobacillus denitrificans and "T. plumbophilus," and Thiodictyon sp. f4 (Table 4; Figure 4).

Five OTUs (9A, 11A, 12A, 14A, 15A) represented aprA sequences ( $4 \%$ of total aprA sequences) related to known SRP in samples $\mathrm{MC}-2 \mathrm{~B}_{(28-34 \mathrm{~cm})}$ and $\mathrm{MC}-3 \mathrm{C}_{(8-16 \mathrm{~cm})}$ (Table 4).

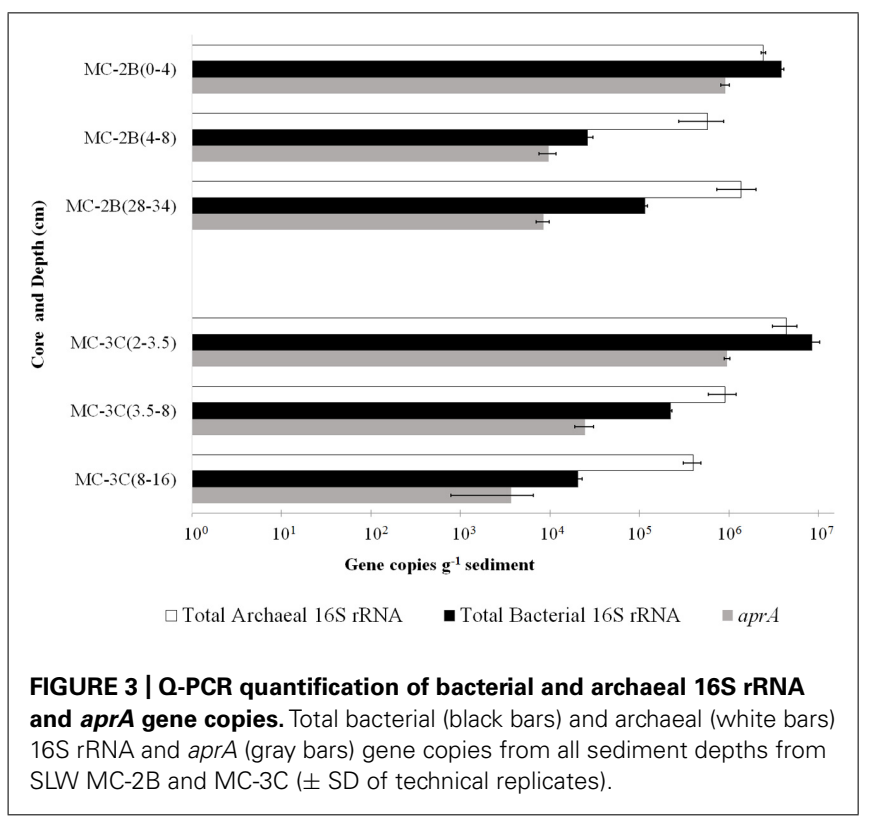

This included Desulfobacterium anilini (95-86\%), Desulfatitalea tepidiphila (95\%), and Desulfotomaculum kuznetsovii (88-80\%; Table 4). aprA OTUs 9A, 14A, and 15A (collectively comprising $3 \%$ of sequences) were most closely related to Desulfobacterium indolicum (95-94\% identity) and the Deltaproteobacterium strain NaphS2 (94-91\% identity). Both of these organisms are known anaerobic sulfate reducers isolated from marine sediments (Bak and Widdel, 1986; Galushko et al., 1999).

Four aprA OTUs (2A, 4A, 6A, and 7A) were designated as 'uncertain' function and represented $23 \%$ of total aprA sequences from SLW sediments (Table 4). The putative function of these sequences could not be designated with certainty (i.e., involved in either sulfur oxidation or sulfate reduction) because these OTUs align with $83-70 \%$ sequence identity to the aprA found in Thermodesulfovibrio spp. and $79-77 \%$ sequence identity to the aprA found in the Chlorobi members including Pelodictyon 
Table 4 | Description of the closest cultured relatives related to SLW aprA OTUs and putative sulfur cycle function.

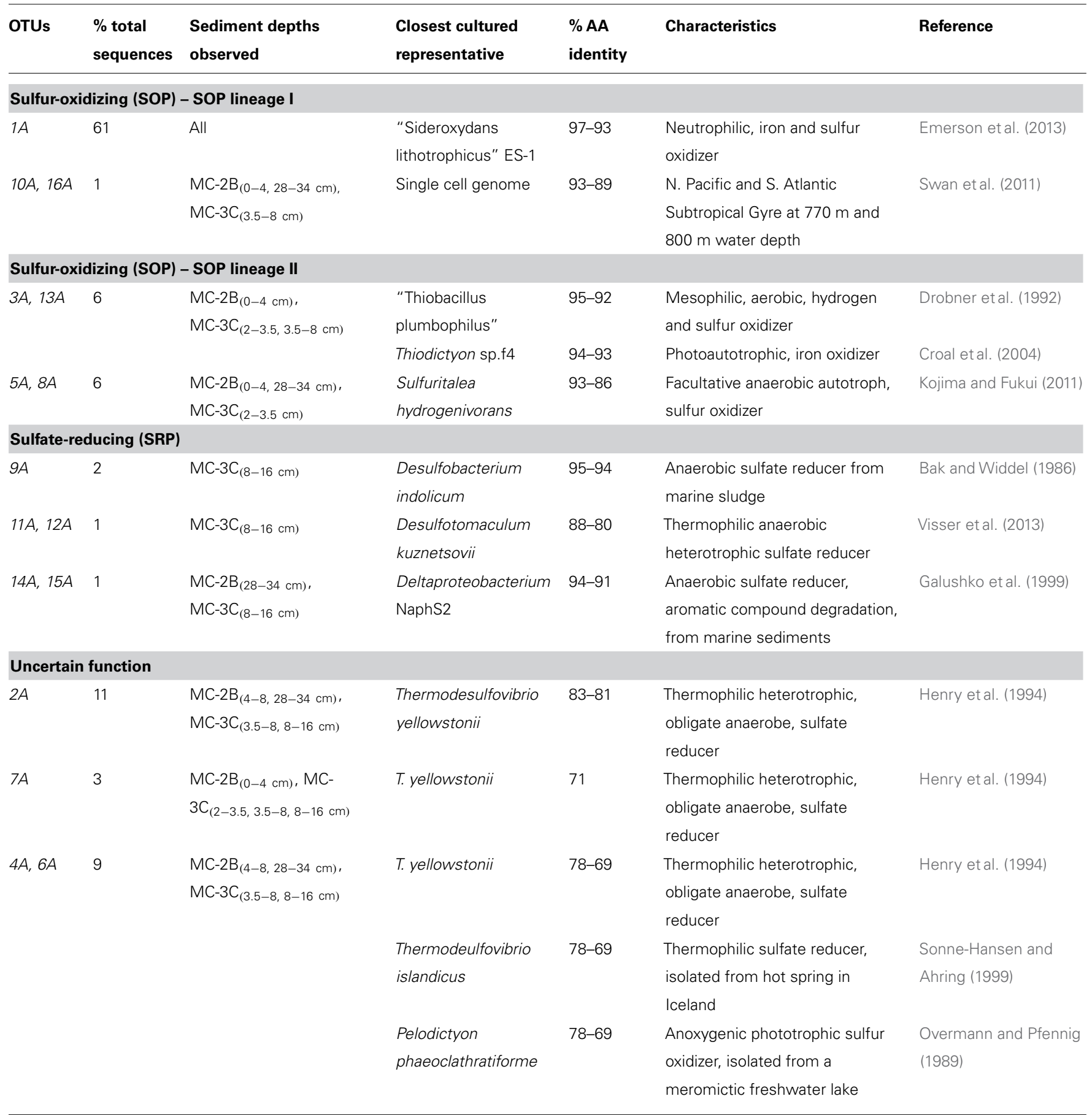

SOP lineages and SRP related aprA are defined by Meyer and Kuever (2007a).

clathratiforme (Table 4). These OTUs also contained an amino acid insertion (data not shown) at position 311 (numbering after aprA in Allochromatium vinosum) that is unique to both the Thermodesulfovibrio and Chlorobiaceae aprA sequences (Meyer and Kuever, 2007b). Detailed molecular analysis has shown that APS genes from Thermodesulfovibrio species has been horizontally transferred to these sulfur-oxidizing anoxygenic phototrophic members of Chlorobiaceae (Meyer and Kuever, 2007b,c). OTU2A was the second most abundant OTU and represented $11 \%$ of total aprA sequences in SLW sediments. This OTU had an $83-81 \%$ amino acid identity to Thermodesulfovibrio yellowstonii, an anaerobic, heterotrophic, sulfate-reducer originally isolated from hydrothermal water (Henry et al., 1994). 


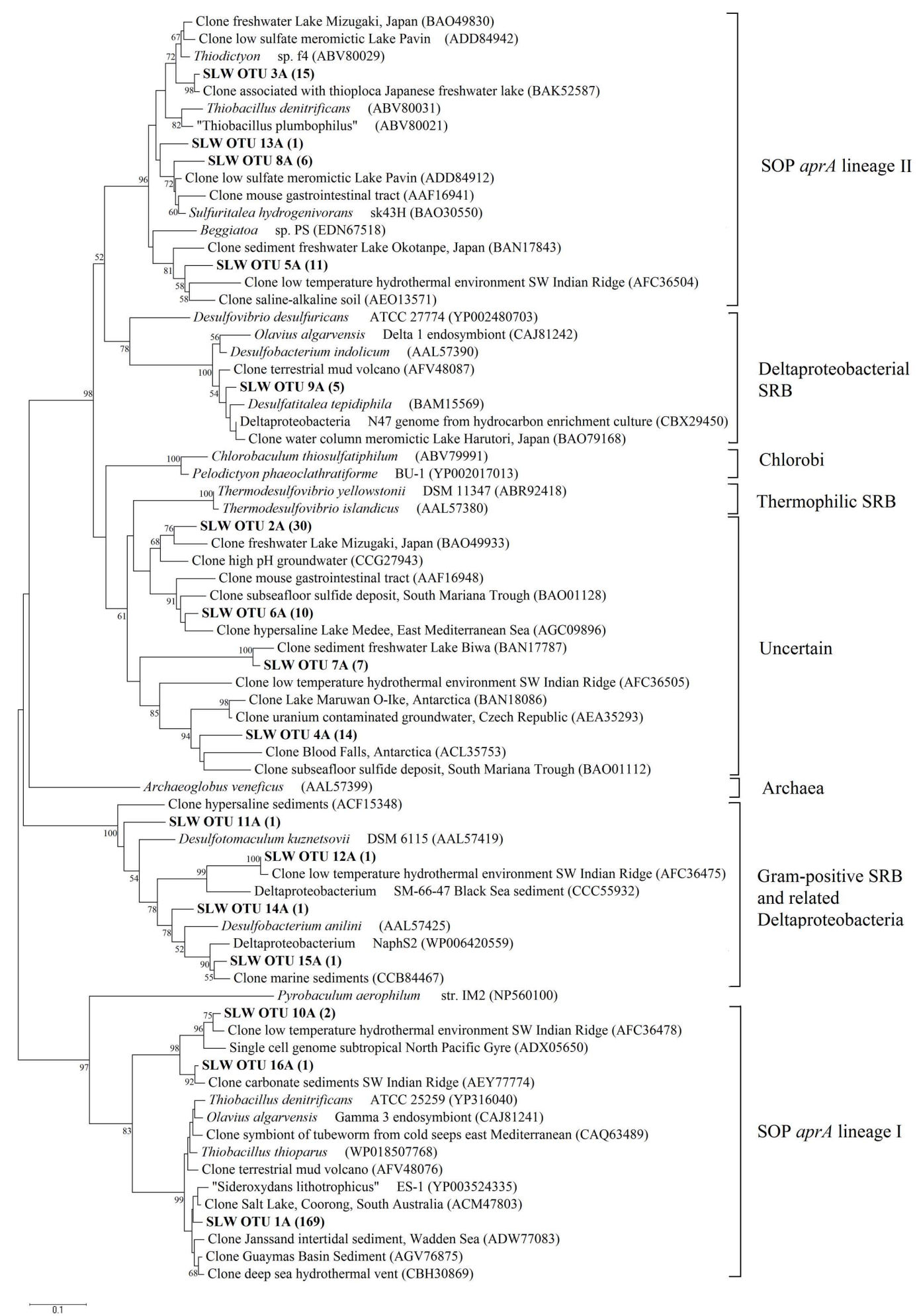

FIGURE 4 | Phylogenetic tree of SLW sediments aprA OTUs.

Neighbor-joining reconstruction of 16 aprA sequences from SLW sediments and the most identical aprA-containing cultured organisms and environmental sequences. Values at nodes indicate bootstrap support from 1000 replicates. One representative aprA sequence from each of the 16 operational taxonomic units (OTUs) was randomly selected and included. SLW aprA OTUs are in bold and the total number of sequences obtained within that OTU are in parentheses. Lineage designations on the right are from Meyer and Kuever (2007c). Pyrobaculum aerophilum was used as an outgroup reference. Scale bar indicates the branch length corresponding to 0.1 substitutions per amino acid position. 


\section{dsrA AND rdsrA GENES}

The primer set targeting a short (221 bp) fragment of $d s r A$ amplified in all sediment samples. The longer $d \operatorname{sr} A B(1.9 \mathrm{~kb})$ fragment only amplified in the deeper sediments; $\mathrm{MC}-2 \mathrm{~B}_{(28-34 \mathrm{~cm})}$ and $\mathrm{MC}-3 \mathrm{C}_{(3.5-8 \text { and } 8-16 \mathrm{~cm})}$ (Table 1) and sequences related to SRP aprA were only detected in $\mathrm{MC}-2 \mathrm{~B}_{(28-34 \mathrm{~cm})}$ and $\mathrm{MC}-3 \mathrm{C}_{(8-16 \mathrm{~cm})}$. Fifty-five $d s r A$ sequences from samples $\mathrm{MC}-2 \mathrm{~B}_{(0-4}$ and $\left.4-8 \mathrm{~cm}\right)$ and $\mathrm{MC}-3 \mathrm{C}_{(2-3.5,3.5-8 \text {, and } 8-16 \mathrm{~cm})}$ formed eight distinct OTUs. The majority of these OTUs ( $80 \%$ total sequences) were $78-73 \%$ identical to $d s r A$ from characterized species in the genera Desulfotomaculum and Carboxydothermus. The remaining sequences were $88-78 \%$ identical to $d s r A$ within the Deltaproteobacteria orders Desulfovibrionales and Desulfobacterales and 99-95\% identical to clones from marine sediments (Blazejak and Schippers, 2011).

To increase resolution of SRP phylogenetic diversity, the alpha subunit (255 amino acids) of the $d s r A B$ gene from 36 clones collected from MC-2B $(28-34 \mathrm{~cm})$ and $\mathrm{MC}-3 \mathrm{C}_{(3.5-8}$ and $\left.8-16 \mathrm{~cm}\right)$ was analyzed. Six distinct OTUs were detected. OTU1D (84\% of sequences) represented a deeply branching $d s r A$ cluster, with 65-64\% sequence identity to $d s r A$ from members of the Desulfotomaculum genus including Desulfotomaculum alkaliphilum and the sulfate-reducing archaeon, Archaeoglobus veneficus. OTU1D was $77-75 \%$ identical to a $d s r A$ environmental clone obtained from various cold marine sediment environments (Harrison et al., 2009; de Rezende et al., 2013). OTU3D (4\% of sequences) was most closely related ( $84 \%$ identity) to $d s r A$ from the sulfatereducing Deltaproteobacteria species Desulfatibacillum alkenivorans, which is capable of both heterotrophic and chemolithoautotrophic growth (Callaghan et al., 2012) and Desulfosalsimonas propionica, a halophilic propionate oxidizer isolated from Great Salt Lake sediments (Kjeldsen et al., 2010). OTUs 2D, 5D, 6D (10\% of $d s r A$ sequences) were $69-64 \%$ identical to Firmicute sequences, including Desulfurispora thermophila, Desulfotomaculum carboxydivorans, and Pelotomaculum propionicum. dsrA OTU4D was 76-72\% identical to Desulfotomaculum carboxydivorans and Desulfurispora thermophila. These organisms are also members of the Firmicutes phyla and are known sporeforming, sulfate-reducers (Parshina et al., 2005; Kaksonen et al., 2007).

Amplification of $r d s r A B$ was detected in $\mathrm{MC}-2 \mathrm{~B}_{(0-4 \mathrm{~cm})}$ and $\mathrm{MC}-3 \mathrm{C}_{(2-3.5}$ and $\left.3.5-8 \mathrm{~cm}\right)$, but not in $\mathrm{MC}-2 \mathrm{~B}_{(4-8}$ and $\left.28-34 \mathrm{~cm}\right)$, or $\mathrm{MC}-3 \mathrm{C}_{(8-12 \mathrm{~cm})}$. Seven unique $r d s r A$ OTUs were detected among the $111 \mathrm{rdsr}$ s sequences retrieved from SLW sediments. The most abundant OTU, 1R (60\% of sequences), was most closely related (83-78\% identity) to members of the Chromatiaceae family including Thiorhodococcus drewsii and Marichromatium purpuratum, which are anoxygenic phototrophs capable of oxidizing hydrogen sulfide (Zaar et al., 2003). OTU2R (28\% of sequences) was $91-88 \%$ identical to $T$. denitrificans and T. thioparus. Three OTUs (3R, 4R, and 6R), represented $12 \%$ of total $r d s r A$ sequences and were $91-80 \%$ identical to "Sideroxydans lithotrophicus" ES-1. The remaining OTUs (5R and $7 \mathrm{R}$ ) represented $2 \%$ of total $r d s r A$ sequences and were 84 $83 \%$ identical to Sulfuritalea hydrogenivorans sk $43 \mathrm{H}$, a facultative anaerobe, mixotroph, and sulfur oxidizer (Kojima and Fukui, 2011).

\section{DISCUSSION}

ABUNDANCE OF MICROBIAL CELLS, 16S rRNA, AND aprA GENE COPIES

Bacterial and archaeal 16S rRNA gene copies varied between cores suggesting SLW sediments were heterogeneous. Our data were consistent with observations from a wide variety of marine sediments (Kallmeyer et al., 2012). Archaeal and bacterial 16S rRNA gene abundances were similar between the two SLW surficial sediment depths studied $\left[\mathrm{MC}-2 \mathrm{~B}_{(0-4} \mathrm{cm}\right)$ and $\mathrm{MC}-3 \mathrm{C}_{(2-3.5 \mathrm{~cm})}$; Table 1; Figure 3]. However, the number of archaeal 16S rRNA gene copies were higher than bacteria in all other samples; MC$2 \mathrm{~B}_{(4-8}$ and $\left.28-34 \mathrm{~cm}\right)$ and $\mathrm{MC}-3 \mathrm{C}_{(3.5-8}$ and $\left.8-16 \mathrm{~cm}\right)$ (Table 1; Figure 3). This contrasts with previous results from SLW surficial sediments. Christner et al. (2014) detected low relative abundance of archaeal phylotypes in the SLW water column and surficial (0$2 \mathrm{~cm}$ ) sediments (3.6 and $0.3 \%$, respectively). This discrepancy could be due to primer bias; the primers used in our Q-PCR analysis detect a wider range of archaea [according to in silico analysis using TestPrime 1.0 application (Klindworth et al., 2012) and the SILVA SSU r119 RefNR database (Quast etal., $\left.2013^{7}\right)$ ]. Alternatively it could be due to heterogeneity. Compiled cell density data (based on both Q-PCR and fluorescence in situ hybridization) from 65 studies of marine sediments showed that abundance of archaea and bacteria vary and dominate at different sites throughout the global ocean (Lloyd et al., 2013).

$16 \mathrm{~S}$ rRNA gene copy number cannot be directly converted into biomass, however, by accounting for average 16S rRNA copy number within sequenced genomes, gene copy number can be used as a proxy for total cells. A survey of the currently finished microbial genomes in JGI IMG (July 2014) indicated that on average there are 4.04 rRNA gene copies per bacteria cell and 1.64 copies per archaeal cells (Markowitz et al., 2014). Based on these values and averaging the Q-PCR results for all depths, we estimated a microbial abundance of $1.6 \times 10^{6}$ cells $\mathrm{g}^{-1}$ wet sediment, which is an order of magnitude higher than our microscopy counts. Numerous protocols have been developed for quantification of microbial cells in sediments using fluorescent nucleic acid stains (Klauth et al., 2004; Kallmeyer et al., 2008; Morono et al., 2013). However, quantification remains challenging due to auto-fluorescent properties of sediment particles, non-specific binding of nucleic acid stains, or particle blocked microbial cells (Kepner and Pratt, 1994). Lloyd et al. (2013) determined that 16S rRNA gene quantification and microscopy cell counts vary and cannot be consistently correlated.

Functional gene abundances relative to total 16S rRNA gene copies have been used to estimate population densities (Henry et al., 2006). Copies of aprA in SLW sediments represented 7.3\% $\left[\mathrm{MC}-2 \mathrm{~B}_{(0-4 \mathrm{~cm})}\right]$ and $14.5 \%\left[\mathrm{MC}-3 \mathrm{C}_{(2-3.5 \mathrm{~cm})}\right]$ of total $16 \mathrm{~S}$ rRNA gene copies in the top depths. These percentages decreased to $1.6 \%$ $\left[\mathrm{MC}-2 \mathrm{~B}_{(4-8)}\right]$ and $2.2 \%\left[\mathrm{MC}-3 \mathrm{C}_{(2-3.5)}\right]$ in the middle depths, and $0.6 \%\left[\mathrm{MC}-2 \mathrm{~B}_{(28-34 \mathrm{~cm})}\right]$ and $0.9 \%\left[\mathrm{MC}-3 \mathrm{C}_{(8-16 \mathrm{~cm})}\right]$ in the deeper depths (Table 1). The aprA primers used for this study are universal for bacteria and archaea, however no archaeal $a p r A$ were detected. If we compare aprA abundance relative to total bacterial $16 \mathrm{~S}$ rRNA, $18 \% \pm 9.9$ of the total bacterial population is represented (Table 1). This proportion is higher than reports

\footnotetext{
${ }^{7}$ http://www.arb-silva.de
} 
from $40 \mathrm{~m}$ below the Peru Margin seafloor, where aprA represented $0.5-1 \%$ of bacterial 16S rRNA gene copies (Blazejak and Schippers, 2011). While the abundance of aprA containing cells varied in our samples, they appear to comprise a large portion of the community.

\section{COMMUNITY STRUCTURE, FUNCTION, AND DIVERSITY IN SLW SEDIMENTS}

The presence of $a p r A, d s r A B$, and $r d s r A B$ in sediments from SLW indicated the microbial community had the genetic potential to mediate a variety of sulfur transformations (Table 1). Functional lineages of aprA (e.g., oxidation, reduction, or uncertain function) varied with depth in both sediment cores (Figure 5) although sulfur-oxidizing aprA was present in all depths analyzed. SOP-like sequences were all related to autotrophs or facultative autotrophs, supporting the potential for sulfur driven chemosynthesis in the top $34 \mathrm{~cm}$ of SLW sediments (Table 4; Figure 5).

Diversity measurements can be used to compare depth profiles or different environments. The Shannon-Weaver diversity index $\left(H^{\prime}\right)$ varied from 0.63 to 1.82 suggesting heterogeneity in sediment samples (Table 3). Sulfur-oxidizing aprA sequences were dominant in the top sediment depths (98\% of total aprA sequences; Figure 6), and had low diversity (Table 3). The abundance of aprA sequences related to sulfur oxidizers decreased with depth (Figure 5), but overall aprA sequence diversity was higher at deeper depths; MC-2B $(28-34 \mathrm{~cm})$ and $\mathrm{MC}-3 \mathrm{C}_{(8-16 \mathrm{~cm})}, H^{\prime}$ values, 1.62 and 1.82, respectively. The diversity in SLW is lower than other, mineral rich environments such as a low temperature hydrothermal field $\left(H^{\prime}=2.3-3.1\right)$ with high concentrations of Fe, $\mathrm{Si}$, and Mn (Li et al., 2013) or organic-rich environments such as Brazilian mangrove sediments $\left(\mathrm{H}^{\prime}=1.9-2.6\right.$; Varon-Lopez et al., 2014). SRP-related aprA sequences were only detected in MC$2 \mathrm{~B}_{(28-34 \mathrm{~cm})}$ and $\mathrm{MC}-3 \mathrm{C}_{(8-16 \mathrm{~cm})}$ (Table 4; Figure 5), suggesting a shift in the sulfur cycling community structure with depth. The total SOP community in SLW was likely undersampled (Table 3; Figure 6) since the alternative oxidation pathways (e.g., the SOX enzyme system), present in many SOP (Meyer et al., 2007), were not addressed in this study.

\section{SULFUR-OXIDIZING PROKARYOTES IN SLW SEDIMENTS}

Combined aprA and $r d s r A$ analyses indicated that the dominant sulfur oxidizer in SLW was related to "Sideroxydans lithotrophicus" ES-1. Strain ES-1 was originally isolated from groundwater in Michigan and has been characterized as a neutrophilic, microaerophilic, iron oxidizer also capable of oxidizing reduced sulfur compounds such as thiosulfate and iron sulfide (Emerson and Moyer, 1997; Emerson et al., 2013). Thiobacillus spp. and Sulfuritalea hydrogenivorans sk $43 \mathrm{H}$, known chemoautotrophs (Kelly, 1982; Drobner et al., 1992; Kojima and Fukui, 2011), were also detected in both aprA and $r d s r A$ clone libraries. The $16 \mathrm{~S} r \mathrm{rNA}$ gene survey on $\mathrm{MC}-2 \mathrm{~B}_{(0-2 \mathrm{~cm})}$ sediments found that a "Sideroxydans"like phylotype was most abundant (12.7\% total sequences) and a Thiobacillus-like phylotype (6.1\% total sequences) was also present (Christner et al., 2014). Our results are also consistent with findings from other subglacial systems. For example, the 16S rRNA gene sequence identified as "Sideroxydans lithotrophicus" from

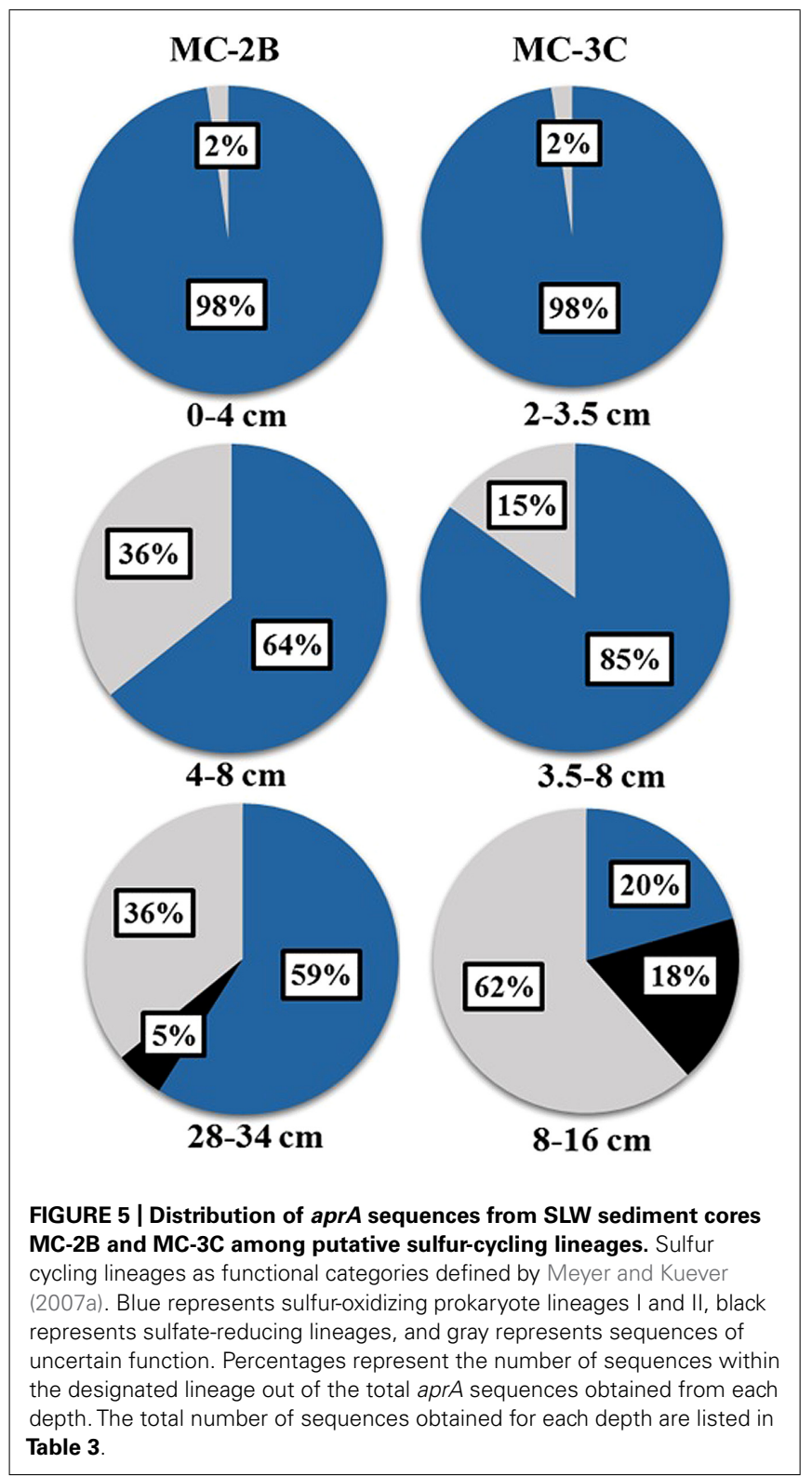

SLW (Christner et al., 2014) was 99\% identical to a clone from sediments beneath the Kamb Ice Stream (Lanoil et al., 2009). Analysis of samples from Robertson Glacier in Canada revealed that a "Sideroxydans" sp. comprised $12 \%$ of $16 \mathrm{~S}$ rRNA transcripts (Hamilton et al., 2013) and is likely the dominant mediator of chemosynthesis via pyrite oxidation in this environment (Boyd et al., 2014). Our aprA sequence data, in combination with previously published 16S rRNA gene data, strongly support the notion that sulfur oxidation is a dominant metabolic process in SLW sediments, largely facilitated by a "Sideroxydans"-like organism. These organisms may play a key role in subglacial microbial ecosystems, perhaps as primary producers.

The rDSR pathway may facilitate a chemosynthetic lifestyle for some SOP in SLW. The most abundant rdsrA OTU (1R) from SLW sediments was most closely related to cultured phototrophs. However, few surveys of rDSR diversity in environmental samples 
have been published, which is in contrast to APS and DSR (Loy et al., 2009). Experiments on isolates show rDSR is necessary for the oxidation of intracellular sulfur globules, temporary storage reservoirs that are formed during the oxidation of sulfides in many SOP (Dahl et al., 2005; Holkenbrink et al., 2011). Physiological studies on the function of rDSR in chemoautotrophs, although limited (Loy etal., 2008), suggests rDSR may be important in energy gain from elemental sulfur in the dark ocean (Anantharaman et al., 2014). It has been suggested that the rDSR/reverse APS reductase pathway for sulfur oxidation is more efficient in environments with low sulfide concentrations (Frigaard and Bryant, 2008; Gregersen et al., 2011; Holkenbrink et al., 2011). Energetic efficiency might convey a competitive advantage to microorganisms in SLW sediments making the rDSR pathway preferred for sulfur oxidation.

\section{SULFATE REDUCTION IN SLW SEDIMENTS}

Functional gene data and activity assays both indicated that SRP are present in SLW sediments, although SRR were extremely low (Table 1; Figure 2). Analysis of 16S rRNA gene libraries also indicated that known sulfate-reducing taxa were not abundant members of the water column $(0.1 \%$ OTUs $)$ or the $\mathrm{MC}-2 \mathrm{~B}_{(0-2 \mathrm{~cm})}$ $(0.02 \%)$ sediment community (Christner etal., 2014). Sulfate reduction was not detected in the SLW water column, likely due to the presence of oxygen. The low measured rates in the sediments could also be due to rapid reoxidation of reduced sulfur. If reduced sulfur generated by SRP activity was reoxidized before it could be scavenged by the zinc trap in our experimental design, our rates would be an underestimation; $\mathrm{FeS}, \mathrm{FeS}_{2}$ and $\mathrm{S}^{2-}$ are not released from solution until the experiment is terminated by passive extraction. A similar process, where reduced sulfur was quantitatively reoxidized to sulfate, described as a catalytic sulfur cycle, was observed in the Blood Falls subglacial brine based on the isotopic composition of sulfate $\delta^{34} S$ and $\delta^{18} \mathrm{O}$ (Mikucki et al., 2009). This type of sulfur cycle has also been detected in marine oxygen-minimum zones and is referred to as a cryptic sulfur cycle (Canfield et al., 2010). Low rates (0.21.0 pmol $\mathrm{cm}^{-3} \mathrm{~d}^{-1}$ ), of the same order of magnitude as SLW, were measured in marine sediments at 3-5 $\mathrm{m}$ depth, which were
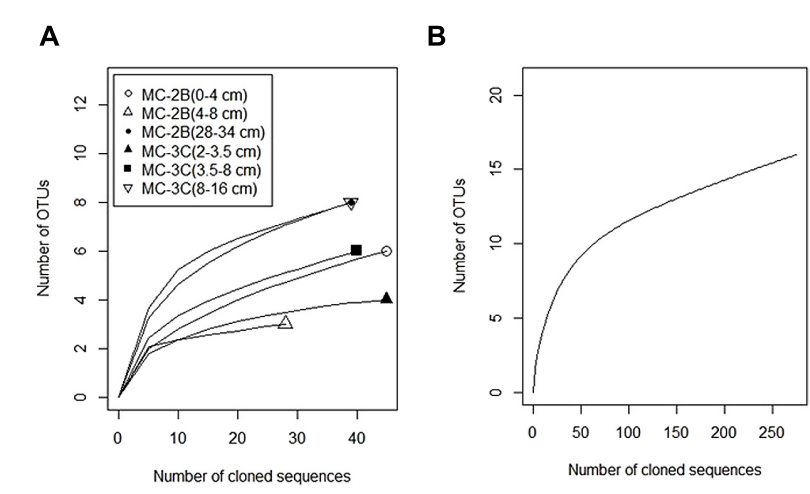

FIGURE 6 | Rarefaction curves of aprA in SLW sediments. (A) Individual depths from sediment cores MC-2B and MC-3C. (B) Total aprA sequences from all depths and cores.
4-5 orders of magnitude less than those measured at the surface (Holmkvist et al., 2011). Rapid turnover of reduced sulfur may be an economical strategy for energy gain in deep subsurface environments.

dsrA was detected in all samples with measureable sulfate reduction; although the distribution of $\operatorname{apr} A$ and $d s r A B$ were less consistent (Table 1; Figure 2). $d s r A B$ abundance may have been below the detection limit, or not detectable with the primer set used. While no aprA sequences related to known SRP were detected in $\mathrm{MC}-2 \mathrm{~B}_{(0-4}$ and $\left.4-8 \mathrm{~cm}\right)$ and $\mathrm{MC}-3 \mathrm{C}_{(2-3.5}$ and $\left.3.5-8 \mathrm{~cm}\right)$, the small amounts of reduced sulfur detected in our SRR experiments from these depths could have been generated by organisms carrying the aprA sequences of uncertain function, (i.e., those related to both Thermodesulfovibrio and members of Chlorobiaceae). For example, aprA OTU 4A, amplified from MC-2B $(4-8 \mathrm{~cm})$ and MC$3 \mathrm{C}_{(3.5-8 \mathrm{~cm})}$ (Table 4), was $83 \%$ identical to a clone from Blood Falls, where sulfate reduction occurs (Mikucki et al., 2009), and both were $74-72 \%$ identical to Thermodesulfovibrio spp, which are known SRP.

MC- $2 \mathrm{~B}_{(28-34 \mathrm{~cm})}$ and $\mathrm{MC}-3 \mathrm{C}_{(8-16 \mathrm{~cm})}$ contained both aprA and $d s r A$ sequences related to Desulfotomaculum spp. and the Deltaproteobacteria family Desulfobacteraceae. It has been argued that Desulfotomaculum spp. play an important ecological role in subsurface environments because they are metabolically plastic. They can grow under a range of sulfate concentrations, use diverse organic substrates, are capable of autotrophy, participate in syntrophic relationships with methanogens, and can form endospores (Imachi et al., 2006; Aüllo et al., 2013). The $d s r A$ sequences from SLW sediments could represent active microorganisms adapted to freshwater, as related sequences have been found in other low sulfate environments (Kondo et al., 2007). Alternatively, given the low sequence similarity to characterized SRP, $d s r A$ detected in this study could represent novel SRP lineages. Most Desulfobacteraceae isolates have been found in marine and hypersaline sediments (Foti et al., 2007; Kjeldsen et al., 2007), however aprA sequences related to this group have also been detected in freshwater lakes (BiderrePetit et al., 2011), including ice-covered lakes Oyako-Ike and Skalle O-Ike in Antarctica (Watanabe et al., 2013). These OTUs could represent organisms that provide reduced sulfur compounds to SOP at deeper sediment depths and use alternative electron acceptors such as nitrate or ferric iron in the absence of oxygen. The concentration of nitrate was higher in the upper $2 \mathrm{~cm}$ of SLW sediments $(9.1 \mu \mathrm{M})$ compared to the water column $(0.8 \mu \mathrm{M}$; Christner et al., 2014), suggesting nitrate is available for microbial reduction. Sulfide oxidation can also be coupled to ferric iron reduction (Schink, 2006), although ferric iron concentrations for SLW have not been processed.

\section{CONCLUSION}

Combined analyses of the functional genes aprA, $d s r A$, and $r d s r A$, in concert with measureable rates of sulfate reduction under anaerobic conditions revealed a diverse community capable of sulfate reduction and sulfur oxidation in SLW sediments. Functional gene OTUs in this study represented groups that encompass a broad range of physiological traits. While some OTUs were related to previously documented species from environments including marine sediments, groundwater, and freshwater lakes, 
many of the OTUs represent novel lineages whose function is not yet known. Our results further support the fact that Antarctic subglacial aquatic environments host a diverse microbial ecosystem that remains inadequately studied. These data provide new insight into the structure of microbial communities in subglacial environments.

The presence of chemosynthetic sulfur oxidizers in SLW surface sediments reinforces previous reports of sulfur oxidation at subglacial sediment-water interfaces (e.g., Tranter et al., 2002; Skidmore et al., 2005; Lanoil et al., 2009; Hamilton et al., 2013) and supports the importance of dark $\mathrm{CO}_{2}$ fixation in subglacial environments (Boyd et al., 2014). We also provide estimates of sulfate reduction rates from samples below the West Antarctic Ice Sheet. Rapid retreat of the grounding line and eventual collapse of the Ross Ice Shelf and West Antarctic Ice Sheet will expose the subglacial ecosystem to marine conditions, as has happened in the past (Mercer, 1978; Scherer et al., 1998). Understanding the structure and function of subglacial microbial communities can help predict the ecological impact of ice sheet thinning or retreat to the proglacial ecosystem.

\section{AUTHOR CONTRIBUTIONS}

Alicia M. Purcell and Jill A. Mikucki designed and conducted the experiments, analyzed the data and wrote the manuscript. Dhritiman Ghosh, Andrew C. Mitchell, John C. Priscu, Mark L. Skidmore, and Alexander B. Michaud assisted with data analyses. Amanda M. Achberger and Brent C. Christner provided input on molecular analyses. Reed Scherer provided sediment descriptions. All authors contributed to sample acquisition, manuscript revisions, and approved the final submitted version.

\section{ACKNOWLEDGMENTS}

This research was supported by the National Science Foundation Office of Polar Programs (NSF-OPP grants 0838896 to Jill A. Mikucki, we are grateful to R. Virginia for assistance; 0839059 to Reed Scherer; 0838941 to Brent C. Christner; 0838933 to John C. Priscu) as part of the WISSARD Project. This research would not have been possible without a wide array of logistic and technical support at all stages of the project. We thank the Antarctic Support Contractor, in particular the traverse crews and the Crary Lab staff, Ken Borek Air, the University of Nebraska, Lincoln hot water drilling team, and the full WISSARD Project science team which includes: W. P. Adkins, S. Anandakrishnan, G. Barcheck, L. Beem, A. Behar, M. Beitch, R. Bolsey, C. Branecky, S. Carter, K. Christianson, R. Edwards, A. Fisher, H. Fricker, N. Foley, B. Guthrie, T. Hodson, R. Jacobel, S. Kelley, K. Mankoff, E. McBryan, R. Powell, D. Sampson, J. Severinghaus, J. Sherve, M. Siegfried, and S. Tulaczyk. We would like to thank K. Lloyd for fruitful discussions related to this manuscript.

\section{REFERENCES}

Anantharaman, K., Duhaime, M. B., Breier, J. A., Wendt, K. A., Toner, B. M., and Dick, G. J. (2014). Sulfur oxidation genes in diverse deep-sea viruses. Science 344, 757-760. doi: 10.1126/science. 1252229

Anderson, S. P. (2007). Biogeochemistry of glacial landscape systems. Annu. Rev. Earth Planet. Sci. 35, 375-399. doi: 10.1126/science.1140766

Antony, C. P., Kumaresan, D., Ferrando, L., Boden, R., Moussard, H., Scavino, A. F., et al. (2010). Active methylotrophs in the sediments of Lonar Lake, a saline and alkaline ecosystem formed by meteor impact. ISME J. 4:11, 1470-1480. doi: 10.1038/ismej.2010.70

Aüllo, T., Ranchou-Peyruse, A., Ollivier, B., and Magot, M. (2013). Desulfotomaculum spp. and related gram-positive sulfate-reducing bacteria in deep subsurface environments. Front. Microbiol. 4:362. doi: 10.3389/fmicb.2013.00362

Bak, F., and Widdel, F. (1986). Anaerobic degradation of phenol and phenol derivatives by Desulfobacterium phenolicum sp. nov. Arch. Microbiol. 146:2, 177-180. doi: 10.1007/BF00402347

Ball, B. A., and Virginia, R. (2014). Microbial biomass and respiration responses to nitrogen fertilization in a polar desert. Polar Biol. 37:4, 573-585. doi: 10.1007/s00300-014-1459-0

Banfield, J. F., Barker, W. W., Welch, S. A., and Taunton, A. (1999). Biological impact on mineral dissolution: application of the lichen model to understanding mineral weathering in the rhizosphere. Proc. Natl. Acad. Sci. U.S.A. 96:7, 3404-3411. doi: 10.1073/pnas.96.7.3404

Biderre-Petit, C., Jézéquel, D., Dugat-Bony, E., Lopes, F., Kuever, J., Borrel, G., et al. (2011). Identification of microbial communities involved in the methane cycle of a freshwater meromictic lake. FEMS Microbiol. Ecol. 77:3, 533-545. doi: 10.1111/j.1574-6941.2011.01134.x

Blazejak, A., and Schippers, A. (2011). Real-time PCR quantification and diversity analysis of the functional genes aprA and dsrA of sulfate-reducing prokaryotes in marine sediments of the Peru continental margin and the Black Sea. Front. Microbiol. 2:253. doi: 10.3389/fmicb.2011.00253

Bottrell, S. H., and Tranter, M. (2002). Sulphide oxidation under partially anoxic conditions at the bed of the Haut Glacier d'Arolla, Switzerland. Hydrol. Process. 16, 2363-2368. doi: 10.1002/hyp.1012

Bowles, M. W., Mogollón, J. M., Kasten, S., Zabel, M., and Hinrichs, K. U. (2014). Global rates of marine sulfate reduction and implications for sub-sea-floor metabolic activities. Science 344, 889-891. doi: 10.1126/science.1249213

Boyd, E. S., Hamilton, T. L., Havig, J. R., Skidmore, M., and Shock, E. L. (2014). Chemolithotrophic primary production in a subglacial ecosystem. Appl. Environ. Microbiol. 80, 6146-6153. doi: 10.1128/AEM.01956-14

Callaghan, A. V., Morris, B. E. L., Pereira, I. A. C., McInerney, M. J., Austin, R. N., Groves, J. T., et al. (2012). The genome sequence of Desulfatibacillum alkenivorans AK-01: a blueprint for anaerobic alkane oxidation. Environ. Microbiol. 14, 101113. doi: 10.1111/j.1462-2920.2011.02516.x

Canfield, D. E., Jørgensen, B. B., Fossing, H., Glud, R., Gundersen, J., Ramsing, N. B., et al. (1993). Pathways of organic carbon oxidation in three continental margin sediments. Mar. Geol. 113, 27-40. doi: 10.1016/0025-3227(93)90147-N

Canfield, D. E., Stewart, F. J., Thamdrup, B., De Brabandere, L., Dalsgaard, T., Delong, E. F., et al. (2010). A cryptic sulfur cycle in oxygen-minimum-zone waters off the Chilean coast. Science 330, 1375-1378. doi: 10.1126/science.1196889

Carter, S. P., and Fricker, H. A. (2012). The supply of subglacial meltwater to the grounding line of the Siple Coast, West Antarctica. Ann. Glaciol. 53, 267-280. doi: 10.3189/2012AoG60A119

Christianson, K., Jacobel, R. W., Horgan, H. J., Anandakrishnan, S., and Alley, R. B. (2012). Subglacial Lake Whillans-Ice-penetrating radar and GPS observations of a shallow active reservoir beneath a West Antarctic ice stream. Earth Planet. Sci. Lett. 331, 237-245. doi: 10.1016/j.epsl.2012.03.013

Christner, B. C., Priscu, J. C., Achberger, A. M., Barbante, C., Carter, S. P., Christianson, K., et al. (2014). Subglacial Lake Whillans: a microbial ecosysytem beneath the West Antarctic Ice Sheet. Nature 512, 310-313. doi: 10.1088/nature13667

Christner, B. C., Royston-Bishop, G., Foreman, C. M., Arnold, B. R., Tranter, M., Welch, K. A., et al. (2006). Limnological conditions in subglacial Lake Vostok, Antarctica. Limnol. Oceanogr. 51, 2485-2501. doi: 10.4319/lo.2006.51.6.2485

Croal, L. R., Johnson, C. M., Beard, B. L., and Newman, D. K. (2004). Iron isotope fractionation by $\mathrm{Fe}$ (II)-oxidizing photoautotrophic bacteria. Geochim. Cosmochim. Acta 68, 1227-1242. doi: 10.1016/j.gca.2003. 09.011

Dahl, C., Engels, S., Pott-Sperling, A. S., Schulte, A., Sander, J., Lübbe, Y., et al. (2005). Novel genes of the dsr gene cluster and evidence for close interaction of Dsr proteins during sulfur oxidation in the phototrophic sulfur bacterium Allochromatium vinosum. J. Bacteriol. 187, 1392-1404. doi: 10.1128/JB.187. 4.1392

de Rezende, J. R., Kjeldsen, K. U., Hubert, C. R., Finster, K., Loy, A., and Jørgensen, B. B. (2013). Dispersal of thermophilic Desulfotomaculum endospores into Baltic Sea sediments over thousands of years. ISME J. 7, 72-84. doi: 10.1038/ismej. 2012.83 
Drobner, E., Huber, H., Rachel, R., and Stetter, K. O. (1992). Thiobacillus plumbophilus spec. nov., a novel galena and hydrogen oxidizer. Arch. Microbiol. 157, 213-217. doi: 10.1007/BF00245152

Ehrlich, H. L. (1996). How microbes influence mineral growth and dissolution. Chem. Geol. 132, 5-9. doi: 10.1016/S0009-2541(96)00035-6

Emerson, D., Field, E. K., Chertkov, O., Davenport, K. W., Goodwin, L., Munk, C., et al. (2013). Comparative genomics of freshwater Fe-oxidizing bacteria: implications for physiology, ecology, and systematics. Front. Microbiol. 4:254. doi: $10.3389 /$ fmicb.2013.00254

Emerson, D., and Moyer, C. (1997). Isolation and characterization of novel ironoxidizing bacteria that grow at circumneutral pH. Appl. Environ. Microbiol. 63, 4784-4792.

Fossing, H., and Jørgensen, B. B. (1989). Measurement of bacterial sulfate reduction in sediments: evaluation of a single-step chromium reduction method. Biogeochemistry 8, 205-222. doi: 10.1007/BF00002889

Foti, M., Sorokin, D. Y., Lomans, B., Mussman, M., Zacharova, E. E., Pimenov, N. V., et al. (2007). Diversity, activity, and abundance of sulfate-reducing bacteria in saline and hypersaline soda lakes. Appl. Environ. Microbiol. 73, 2093-2100. doi: 10.1128/AEM.02622-06

Fricker, H. A., Powell, R., Priscu, J., Tulaczyk, S., Anandakrishnan, S., Christner, B., et al. (2011). Siple coast subglacial aquatic environments: the Whillans Ice Stream subglacial access research drilling project. Geophys. Monogr. Ser. 192, 199-219. doi: $10.1002 / 9781118670354 . c h 12$

Fricker, H. A., and Scambos, T. (2009). Connected subglacial lake activity on lower Mercer and Whillans Ice Streams, West Antarctica, 2003-2008. J. Glaciol. 55:190, 303-315. doi: 10.3189/002214309788608813

Fricker, H. A., Scambos, T., Bindschadler, R., and Padman, L. (2007). An active subglacial water system in West Antarctica mapped from space. Science 315, 1544 1548. doi: 10.1126/science. 1136897

Friedrich, C. G., Bardischewsky, F., Rother, D., Quentmeier, A., and Fischer, J. (2005). Prokaryotic sulfur oxidation. Curr. Opin. Microbiol. 8, 253-259. doi: 10.1128/AEM.67.7.2873

Friedrich, C. G., Rother, D., Bardischewsky, F., Quentmeier, A., and Fischer, J. (2001). Oxidation of reduced inorganic sulfur compounds by bacteria: emergence of a common mechanism. Appl. Environ. Microbiol. 67:7, 2873-2882. doi: 10.1128/AEM.67.7.2873-2882.2001

Frigaard, N.-U., and Bryant, D. A. (2008). "Genomics insights into the sulfur metabolism of phototrophic green sulfur bacteria," in Advances in Photosynthesis and Respiration, eds R. Hell, C. Dahl, D. B. Knaff, and T. Leustek. (Heidelberg: Springer), 337-355. doi: 10.1007/978-1-4020-6863-8_17

Galushko, A., Minz, D., Schink, B., and Widdel, F. (1999). Anaerobic degradation of naphthalene by a pure culture of a novel type of marine sulphate-reducing bacterium. Environ. Microbiol. 1, 415-420. doi: 10.1046/j.1462-2920.1999. 00051.x

Good, I. J. (1953). The population frequencies of species and the estimation of population parameters. Biometrika 40, 237-264. doi: 10.1093/biomet/40. 3-4.237

Green-Saxena, A., Feyzullayev, A., Hubert, C. R., Kallmeyer, J., Krueger, M., Sauer, P., et al. (2012). Active sulfur cycling by diverse mesophilic and thermophilic microorganisms in terrestrial mud volcanoes of Azerbaijan. Environ. Microbiol. 14, 3271-3286. doi: 10.1111/1462-2920.12015

Gregersen, L. H., Bryant, D. A., and Frigaard, N. U. (2011). Mechanisms and evolution of oxidative sulfur metabolism in green sulfur bacteria. Front. Microbiol. 2:116. doi: $10.3389 /$ fmicb. 2011.00116

Hall, T. A. (1999). BioEdit: a user-friendly biological sequence alignment editor and analysis program for Windows 95/98/NT. Nucleic Acids Symp. Ser. 41, 95-98.

Hamilton, T. L., Peters, J. W., Skidmore, M. L., and Boyd, E. S. (2013). Molecular evidence for an active endogenous microbiome beneath glacial ice. ISME J. 7, 1402-1412. doi: 10.1038/ismej.2013.3

Haran, T., Bohlander, J., Scambos, T., and Fahnestock, M. (2005). MODIS mosaic of Antarctica (MOA) image map. NSIDC Digital Media. Available at: http://nsidc.org/data/nsidc-0280

Harrison, B. K., Zhang, H., Berelson, W., and Orphan, V. J. (2009). Variations in archaeal and bacterial diversity associated with the sulfate-methane transition zone in continental margin sediments (Santa Barbara Basin, California). Appl. Environ. Microbiol. 75, 1487-1499. doi: 10.1128/AEM. 01812-08
Henry, E. A., Devereux, R., Maki, J. S., Gilmour, C. C., Woese, C. R., Mandelco, L., et al. (1994). Characterization of a new thermophilic sulfate-reducing bacterium. Arch. Microbiol. 161, 62-69. doi: 10.1007/BF00248894

Henry, S., Bru, D., Stres, B., Hallet, S., and Philippot, L. (2006). Quantitative detection of the nosZ gene, encoding nitrous oxide reductase, and comparison of the abundances of $16 \mathrm{~S}$ rRNA, narG, nirK, and nosZ genes in soils. Appl. Environ. Microbiol. 72, 5181-5189. doi: 10.1128/AEM.00231-06

Hill, T. C., Walsh, K. A., Harris, J. A., and Moffett, B. F. (2003). Using ecological diversity measures with bacterial communities. FEMS Microbiol. Ecol. 43, 1-11. doi: 10.1111/j.1574-6941.2003.tb01040.x

Holkenbrink, C., Barbas, S. O., Mellerup, A., Otaki, H., and Frigaard, N. U. (2011). Sulfur globule oxidation in green sulfur bacteria is dependent on the dissimilatory sulfite reductase system. Microbiology 157, 1229-1239. doi: 10.1099/mic.0.044669-0

Holmkvist, L., Ferdelman, T. G., and Jørgensen, B. B. (2011). A cryptic sulfur cycle driven by iron in the methane zone of marine sediment (Aarhus Bay, Denmark). Geochim. Cosmochim. Acta 75, 3581-3599. doi: 10.1016/j.gca.2011.03.033

Huber, T., Faulkner, G., and Hugenholtz, P. (2004). Bellerophon: a program to detect chimeric sequences in multiple sequence alignments. Bioinformatics 20, 2317-2319. doi: 10.1093/bioinformatics/bth226

Imachi, H., Sekiguchi, Y., Kamagata, Y., Loy, A., Qiu, Y. L., Hugenholtz, P., et al. (2006). Non-sulfate-reducing, syntrophic bacteria affiliated with Desulfotomaculum cluster I are widely distributed in methanogenic environments. Appl. Environ. Microbiol. 72, 2080-2091. doi: 10.1128/AEM.72.3.2080-2091.2006

Jørgensen, B. B. (1982). Mineralization of organic matter in the sea bed-the role of sulphate reduction. Nature 296, 643-645. doi: 10.1038/296643a0

Jørgensen, B. B., and Postgate, J. R. (1982). Ecology of the bacteria of the sulphur cycle with special reference to anoxic-oxic interface environments. Philos. Trans. R. Soc. Lond. B Biol. Sci. 298, 543-561. doi: 10.1098/rstb.1982.0096

Kaksonen, A. H., Spring, S., Schumann, P., Kroppenstedt, R. M., and Puhakka, J. A. (2007). Desulfurispora thermophila gen. nov., sp. nov., a thermophilic, sporeforming sulfate-reducer isolated from a sulfidogenic fluidized-bed reactor. Int. J. Syst. Evol. Microbiol. 57, 1089-1094. doi: 10.1099/ijs.0.64593-0

Kallmeyer, J., Pockalny, R., Adhikari, R. R., Smith, D. C., and D’Hondt, S. (2012). Global distribution of microbial abundance and biomass in subseafloor sediment. Proc. Natl. Acad. Sci. U.S.A. 109, 16213-16216. doi: 10.1073/pnas. 1203849109

Kallmeyer, J., Smith, D. C., Spivack, A. J., and D'Hondt, S. (2008). New cell extraction procedure applied to deep subsurface sediments. Limnol. Oceanogr. Methods 6, 236-245. doi: 10.4319/lom.2008.6.236

Kelly, D. P. (1982). Biochemistry of the chemolithotrophic oxidation of inorganic sulphur. Philos. Trans. R. Soc. Lond. B Biol. Sci. 298, 499-528. doi: 10.1098/rstb.1982.0094

Kepner, R. L., and Pratt, J. R. (1994). Use of fluorochromes for direct enumeration of total bacteria in environmental samples: past and present. Microbiol. Rev. 58, 603-615.

Kjeldsen, K. U., Jakobsen, T. F., Glastrup, J., and Ingvorsen, K. (2010). Desulfosalsimonas propionicica gen. nov., sp. nov., a halophilic, sulfate-reducing member of the family Desulfobacteraceae isolated from a salt-lake sediment. Int. J. Syst. Evol. Microbiol. 60, 1060-1065. doi: 10.1099/ijs.0.014746-0

Kjeldsen, K. U., Loy, A., Jakobsen, T. F., Thomsen, T. R., Wagner, M., and Ingvorsen, K. (2007). Diversity of sulfate-reducing bacteria from an extreme hypersaline sediment, Great Salt Lake (Utah). FEMS Microbiol. Ecol. 60, 287-298. doi: 10.1111/j.1574-6941.2007.00288.x

Klauth, P., Wilhelm, R., Klumpp, E., Poschen, L., and Groeneweg, J. (2004). Enumeration of soil bacteria with the green fluorescent nucleic acid dye Sytox green in the presence of soil particles. J. Microbiol. Methods 59, 189-198. doi: 10.1016/j.mimet.2004.07.004

Klindworth, A., Pruesse, E., Schweer, T., Peplies, J., Quast, C., Horn, M., et al. (2012). Evaluation of general 16 S ribosomal RNA gene PCR primers for classical and next-generation sequencing-based diversity studies. Nucleic Acids Res. 41:e1. doi: $10.1093 /$ nar/gks 808

Kojima, H., and Fukui, M. (2011). Sulfuritalea hydrogenivorans gen. nov., sp. nov., a facultative autotroph isolated from a freshwater lake. Int. J. Syst. Evol. Microbiol. 61, 1651-1655. doi: 10.1099/ijs.0.024968-0

Kondo, R., Nedwell, D. B., Purdy, K. J., and Silva, S. Q. (2004). Detection and enumeration of sulphate-reducing bacteria in estuarine sediments by competitive PCR. Geomicrobiol. J. 21, 145-157. doi: 10.1080/01490450490275307 
Kondo, R., Purdy, K. J., Silva, S. D. Q., and Nedwell, D. B. (2007). Spatial dynamics of sulphate-reducing bacterial compositions in sediment along a salinity gradient in a UK estuary. Microbes Environ. 22, 11-19. doi: 10.1264/jsme2.22.11

Lanoil, B., Skidmore, M., Priscu, J. C., Han, S., Foo, W., Vogel, S. W., et al. (2009). Bacteria beneath the West Antarctic Ice Sheet. Environ. Microbiol. 11, 609-615. doi: 10.1111/j.1462-2920.2008.01831.x

Larkin, M. A., Blackshields, G., Brown, N. P., Chenna, R., McGettigan, P. A., McWilliam, H., et al. (2007). Clustal W and Clustal X version 2.0. Bioinformatics 23, 2947-2948. doi: 10.1093/bioinformatics/btm404

Leloup, J., Fossing, H., Kohls, K., Holmkvist, L., Borowski, C., and Jørgensen, B. B. (2009). Sulfate-reducing bacteria in marine sediment (Aarhus Bay, Denmark): abundance and diversity related to geochemical zonation. Environ. Microbiol. 11, 1278-1291. doi: 10.1111/j.1462-2920.2008.01855.x

Lenk, S., Arnds, J., Zerjatke, K., Musat, N., Amann, R., and Mußmann, M. (2011). Novel groups of Gammaproteobacteria catalyse sulfur oxidation and carbon fixation in a coastal, intertidal sediment. Environ. Microbiol. 13, 758-774. doi 10.1111/j.1462-2920.2010.02380.x

Li, J., Peng, X., Zhou, H., Li, J., and Sun, Z. (2013). Molecular evidence for microorganisms participating in $\mathrm{Fe}, \mathrm{Mn}$, and $\mathrm{S}$ biogeochemical cycling in two low-temperature hydrothermal fields at the Southwest Indian Ridge. J. Geophys. Res. Biogeosci. 118, 665-679. doi: 10.1002/jgrg.20057

Lloyd, K. G., Alperin, M. J., and Teske, A. (2011). Environmental evidence for net methane production and oxidation in putative ANaerobic MEthanotrophic (ANME) archaea. Environ. Microbiol. 13, 2548-2564. doi: 10.1111/j.14622920.2011.02526.x

Lloyd, K. G., May, M. K., Kevorkian, R. T., and Steen, A. D. (2013). Metaanalysis of quantification methods shows that Archaea and Bacteria have similar abundances in the subseafloor. Appl. Environ. Microbiol. 79, 7790-7799. doi: 10.1128/AEM.02090-13

Loy, A., Duller, S., Baranyi, C., Mußmann, M., Ott, J., Sharon, I., et al. (2009). Reverse dissimilatory sulfite reductase as phylogenetic marker for a subgroup of sulfur-oxidizing prokaryotes. Environ. Microbiol. 11, 289-299. doi: 10.1111/j.1462-2920.2008.01760.x

Loy, A., Duller, S., and Wagner, M. (2008). "Evolution and ecology of microbes dissimilating sulfur compounds: insights from siroheme sulfite reductases," in Microbial Sulfur Metabolism, eds C. Dahl and C. G. Friedrich (Heidelberg: Springer), 46-59.

Markowitz, V. M., Chen, I. M., Palaniappan, K., Chu, K., Szeto, E., Pillay, M., et al. (2014). IMG 4 version of the integrated microbial genomes comparative analysis system. Nucleic Acids Res. 42, D560-D567. doi: 10.1093/nar/gkt963

Mattes, T. E., Nunn, B. L., Marshall, K. T., Proskurowski, G., Kelley, D. S., Kawka, O. E., et al. (2013). Sulfur oxidizers dominate carbon fixation at a biogeochemical hot spot in the dark ocean. ISME J. 7, 2349-2360. doi: 10.1038/ismej.2013.113

Mercer, J. H. (1978). West Antarctic ice sheet and CO2 greenhouse effect: a threat of disaster. Nature 271, 321-325. doi: 10.1038/271321a0

Meyer, B., Imhoff, J. F., and Kuever, J. (2007). Molecular analysis of the distribution and phylogeny of the soxB gene among sulfur-oxidizing bacteria-evolution of the Sox sulfur oxidation enzyme system. Environ. Microbiol. 9, 2957-2977. doi: 10.1111/j.1462-2920.2007.01407.x

Meyer, B., and Kuever, J. (2007a). Molecular analysis of the distribution and phylogeny of dissimilatory adenosine- $5^{\prime}$-phosphosulfate reductase-encoding genes (aprBA) among sulfur-oxidizing prokaryotes. Microbiology 153, 3478-3498. doi: 10.1099/mic.0.2007/008250-0

Meyer, B., and Kuever, J. (2007b). Phylogeny of the alpha and beta subunits of the dissimilatory adenosine- $5^{\prime}$-phosphosulfate (APS) reductase from sulfate-reducing prokaryotes-origin and evolution of the dissimilatory sulfatereduction pathway. Microbiology 153, 2026-2044. doi: 10.1099/mic.0.2006/ 003152-0

Meyer, B., and Kuever, J. (2007c). Molecular analysis of the diversity of sulfatereducing and sulfur-oxidizing prokaryotes in the environment, using aprA as functional marker gene. Appl. Environ. Microbiol. 73, 7664-7679. doi: 10.1128/AEM.01272-07

Mikucki, J., Pearson, A., Johnston, D. T., Turchyn, A. V., Farquhar, J., Schrag, D. P. et al. (2009). A contemporary microbially maintained subglacial ferrous ocean. Science 324, 397-400. doi: 10.1126/science.1167350

Mikucki, J. A., and Priscu, J. C. (2007). Bacterial diversity associated with Blood Falls, a subglacial outflow from the Taylor Glacier, Antarctica. Appl. Environ. Microbiol. 73, 4029-4039. doi: 10.1128/AEM.01396-06
Montross, S. N., Skidmore, M., Tranter, M., Kivimäki, A. L., and Parkes, R. J. (2013). A microbial driver of chemical weathering in glaciated systems. Geology 41, 215-218. doi: 10.1130/G33572.1

Morono, Y., Terada, T., Kallmeyer, J., and Inagaki, F. (2013). An improved cell separation technique for marine subsurface sediments: applications for highthroughput analysis using flow cytometry and cell sorting. Environ. Microbiol. 15, 2841-2849. doi: 10.1111/1462-2920.12153

Nadkarni, M. A., Martin, F. E., Jacques, N. A., and Hunter, N. (2002). Determination of bacterial load by real-time PCR using a broad-range (universal) probe and primers set. Microbiology 148, 257-266.

Nilsson, R. H., Abarenkov, K., Veldre, V., Nylinder, S., De Wit, P., Brosché, S., et al. (2010). An open source chimera checker for the fungal ITS region. Mol. Ecol. Res. 10, 1076-1081. doi: 10.1111/j.1755-0998.2010.02850.x

Overmann, J., and Pfennig, N. (1989). Pelodictyon phaeoclathratiforme sp. nov., a new brown-colored member of the Chlorobiaceae forming net-like colonies. Arch. Microbiol. 152, 401-406. doi: 10.1007/BF00425181

Parshina, S. N., Sipma, J., Nakashimada, Y., Henstra, A. M., Smidt, H., Lysenko, A. M., et al. (2005). Desulfotomaculum carboxydivorans sp. nov., a novel sulfatereducing bacterium capable of growth at $100 \%$ CO. Int. J. Syst. Evol. Microbiol. 55, 2159-2165. doi: 10.1099/ijs.0.63780-0

Pott, A. S., and Dahl, C. (1998). Sirohem sulfite reductase and other proteins encoded by genes at the dsr locus of Chromatium vinosum are involved in the oxidation of intracellular sulfur. Microbiology 144, 1881-1894. doi: 10.1099/00221287-144-71881

Priscu, J. C., Achberger, A. M., Cahoon, J. E., Christner, B. C., Edwards, R. L., Jones, W. L., et al. (2013). A microbiologically clean strategy for access to the Whillans Ice Stream subglacial environment. Antarct. Sci. 25, 637-647. doi: 10.1017/S0954102013000035

Priscu, J. C., Powell, R. D., and Tulaczyk, S. (2010). Probing subglacial environments under the Whillans Ice Stream. Eos Trans. Am. Geophys. Un. 91, 253. doi: 10.1029/2010EO290002

Priscu, J. C., Tulaczyk, S., Studinger, M., Kennicutt, M. C. II., Christner, B. C., and Foreman, C. M. (2008). "Antarctic subglacial water: origin, evolution and ecology," in Polar Lakes Rivers, eds W. F. Vincent and J. Laybourn-Parry (Oxford; Oxford UniversityPress), 119-136.

Quast, C., Pruesse, E., Yilmaz, P., Gerken, J., Schweer, T., Yarza, P., et al. (2013). The SILVA ribosomal RNA gene database project: improved data processing and web-based tools. Nucleic Acids Res. 41, D590-D596. doi: 10.1093/nar/gks1219

Rabus, R., Hansen, T. A., and Widdel, F. (2006). "Dissimilatory sulfate-and sulfur-reducing prokaryotes," in The Prokaryotes, eds M. Dworkin, S. Falkow, E. Rosenburg, K. Schleifer, and E. Stackebrandt (New York: Springer), 659-768.

R Development Core Team. (2008). R: a language and environment for statistical computing. R Foundation for Statistical Computing, Vienna, Austria. Available at: http://www.R-project.org

Riedinger, N., Brunner, B., Lin, Y. S., Voßmeyer, A., Ferdelman, T. G., and Jørgensen, B. B. (2010). Methane at the sediment-water transition in Black Sea sediments. Chem. Geol. 274, 29-37. doi: 10.1016/j.chemgeo.2010.03.010

Ritalahti, K. M., Amos, B. K., Sung, Y., Wu, Q., Koenigsberg, S. S., and Löffler, F. E. (2006). Quantitative PCR targeting 16S rRNA and reductive dehalogenase genes simultaneously monitors multiple Dehalococcoides strains. Appl. Environ. Microbiol. 72, 2765-2774. doi: 10.1128/AEM.72.4.2765

Scherer, R. P., Aldahan, A., Tulaczyk, S., Possnert, G., Engelhardt, H., and Kamb, B. (1998). Pleistocene collapse of the West Antarctic ice sheet. Science 281, 82-85. doi: $10.1126 /$ science.281.5373.82

Schink, B. (2006). Microbially driven redox reactions in anoxic environments: pathways, energetics, and biochemical consequences. Eng. Life Sci. 6, 228-233. doi: 10.1002/elsc. 200620130

Siegfried, M. R., Fricker, H. A., Roberts, M., Scambos, T. A., and Tulaczyk, S. (2014). A decade of West Antarctic subglacial lake interactions from combined ICESat and CryoSat-2 altimetry. Geophys. Res. Lett. 41, 891-898. doi: 10.1002/2013GL 058616

Singleton, D. R., Furlong, M. A., Rathbun, S. L., and Whitman, W. B. (2001). Quantitative comparisons of $16 \mathrm{~S}$ rRNA gene sequence libraries from environmental samples. Appl. Environ. Microbiol. 67, 4374-4376. doi: 10.1128/AEM.67.9.4374

Skidmore, M. (2011). "Microbial communities in Antarctic subglacial aquatic environments," in Antarctic Subglacial Aquatic Environ, eds M. Siegert, M. C. Kennicutt, and R. A. Bindschadler (Washington, DC: American Geophysical Union Press), 61-81. doi: 10.1029/2010GM000995 
Skidmore, M., Anderson, S. P., Sharp, M., Foght, J., and Lanoil, B. D. (2005). Comparison of microbial community compositions of two subglacial environments reveals a possible role for microbes in chemical weathering processes. Appl. Environ. Microbiol. 71, 6986-6997. doi: 10.1128/AEM.71.11.6986

Skidmore, M., Tranter, M., Tulaczyk, S., and Lanoil, B. (2010). Hydrochemistry of ice stream beds - evaporitic or microbial effects? Hydrol. Process. 24, 517-523. doi: 10.1002/hyp.7580

Skidmore, M. L., Foght, J. M., and Sharp, M. J. (2000). Microbial life beneath a high Arctic glacier. Appl. Environ. Microbiol. 66, 3214-3220. doi: 10.1128/AEM.66.8.3214-3220.2000

Smith, C. J., and Osborn, A. M. (2009). Advantages and limitations of quantitative PCR (Q-PCR)-based approaches in microbial ecology. FEMS Microbiol. Ecol. 67, 6-20. doi: 10.1111/j.1574-6941.2008.00629.x

Sonne-Hansen, J., and Ahring, B. K. (1999). Thermodesulfobacterium hveragerdense sp. nov., and Thermodesulfovibrio islandicus sp. nov., two thermophilic sulfate reducing bacteria isolated from a Icelandic hot spring. Syst. Appl. Microbiol. 22, 559-564. doi: 10.1016/S0723-2020(99)80009-5

Swan, B. K., Martinez-Garcia, M., Preston, C. M., Sczyrba, A., Woyke, T., Lamy, D., et al. (2011). Potential for chemolithoautotrophy among ubiquitous bacteria lineages in the dark ocean. Science 333, 1296-1300. doi: 10.1126/science.1203690

Takai, K., and Horikoshi, K. (2000). Rapid detection and quantification of members of the archaeal community by quantitative PCR using fluorogenic probes. Appl. Environ. Microbiol. 66, 5066-5072. doi: 10.1128/AEM.66.11.5066-5072.2000

Tamura, K., Peterson, D., Peterson, N., Stecher, G., Nei, M., and Kumar, S. (2013). MEGA6: molecular evolutionary genetics analysis version 6.0. Mol. Biol. Evol. 30, 2725-2729. doi: 10.1093/molbev/mst197

Thullner, M., Dale, A. W., and Regnier, P. (2009). Global-scale quantification of mineralization pathways in marine sediments: a reaction-transport modeling approach. Geochem. Geophys. Geosyst. 10, 1-24. doi: 10.1029/2009GC002484

Tranter, M., Sharp, M. J., Lamb, H. R., Brown, G. H., Hubbard, B. P., and Willis, I. C. (2002). Geochemical weathering at the bed of Haut Glacier d'Arolla, Switzerland-a new model. Hydrol. Process. 16, 959-993. doi: 10.1002/hyp.309

Tranter, M., Skidmore, M., and Wadham, J. (2005). Hydrological controls on microbial communities in subglacial environments. Hydrol. Process. 19, 995-998. doi: 10.1002/hyp. 5854

Tulaczyk, S., Mikucki, J. A., Siegfried, M. R., Priscu, J. C., Barcheck, C. G., Beem, L. H., et al. (2014). WISSARD at Subglacial Lake Whillans, West Antarctica: scientific operations and initial observations. Ann. Glaciol. 55, 51-58. doi: 10.3189/2014AoG65A009

Ulrich, G. A., Krumholz, L. R., and Suflita, J. M. (1997). A rapid and simple method for estimating sulfate reduction activity and quantifying inorganic sulfides. Appl. Environ. Microbiol. 63, 1627-1630.

Varon-Lopez, M., Dias, A. C. F., Fasanella, C. C., Durrer, A., Melo, I. S., Kuramae, E. E., et al. (2014). Sulphur-oxidizing and sulphate-reducing communities in Brazilian mangrove sediments. Environ. Microbiol. 16, 845-855. doi: 10.1111/1462-2920.12237

Visser, M., Worm, P., Muyzer, G., Pereira, I. A., Schaap, P. J., Plugge, C. M., et al. (2013). Genome analysis of Desulfotomaculum kuznetsovii strain 17T reveals a physiological similarity with Pelotomaculum thermopropionicum strain SIT. Stand. Genomic Sci. 8, 69-87. doi: 10.4056/sigs.3627141
Wadham, J. L., Bottrell, S., Tranter, M., and Raiswell, R. (2004). Stable isotope evidence for microbial sulphate reduction at the bed of a polythermal high Arctic glacier. Earth Planet. Sci. Lett. 219, 341-355. doi: 10.1016/S0012821X(03)00683-6

Wadham, J. L., Tranter, M., Skidmore, M., Hodson, A. J., Priscu, J., Lyons, W. B., et al. (2010). Biogeochemical weathering under ice: size matters. Global Biogeochem. Cycles 24:GB3025. doi: 10.1029/2009GB003688

Wagner, M., Roger, A. J., Flax, J. L., Brusseau, G. A., and Stahl, D. A. (1998). Phylogeny of dissimilatory sulfite reductases supports an early origin of sulfate respiration. J. Bacteriol. 180, 2975-2982.

Watanabe, T., Kojima, H., Takano, Y., and Fukui, M. (2013). Diversity of sulfur-cycle prokaryotes in freshwater lake sediments investigated using aprA as the functional marker gene. Syst. Appl. Microbiol. 36, 436-443. doi: 10.1016/j.syapm.2013. 04.009

Wright, A., and Siegert, M. (2012). A fourth inventory of Antarctic subglacial lakes. Antarct. Sci. 24, 659-664. doi: 10.1017/S095410201200048X

Yu, Y., Lee, C., Kim, J., and Hwang, S. (2005). Group-specific primer and probe sets to detect methanogenic communities using quantitative real-time polymerase chain reaction. Biotechnol. Bioengin. 89, 670-679. doi: 10.1002/bit. 20347

Zaar, A., Fuchs, G., Golecki, J. R., and Overmann, J. (2003). A new purple sulfur bacterium isolated from a littoral microbial mat, Thiorhodococcus drewsii sp. nov. Arch. Microbiol. 179, 174-183. doi: 10.1007/s00203-0020514-3

Zverlov, V., Klein, M., Lücker, S., Friedrich, M. W., Kellermann, J., Stahl, D. A., etal. (2005). Lateral gene transfer of dissimilatory (bi) sulfite reductase revisited. J. Bacteriol. 187, 2203-2208. doi: 10.1128/JB.187. 6.2203

Conflict of Interest Statement: The authors declare that the research was conducted in the absence of any commercial or financial relationships that could be construed as a potential conflict of interest.

Received: 08 August 2014; accepted: 21 October 2014; published online: 19 November 2014.

Citation: Purcell AM, Mikucki JA, Achberger AM, Alekhina IA, Barbante C, Christner BC, Ghosh D, Michaud AB, Mitchell AC, Priscu JC, Scherer R, Skidmore ML, Vick-Majors TJ and WISSARD Science Team (2014) Microbial sulfur transformations in sediments from Subglacial Lake Whillans. Front. Microbiol. 5:594. doi: $10.3389 /$ fmicb.2014.00594

This article was submitted to Extreme Microbiology, a section of the journal Frontiers in Microbiology.

Copyright (c) 2014 Purcell, Mikucki, Achberger, Alekhina, Barbante, Christner, Ghosh, Michaud, Mitchell, Priscu, Scherer, Skidmore, Vick-Majors and WISSARD Science Team. This is an open-access article distributed under the terms of the Creative Commons Attribution License (CC BY). The use, distribution or reproduction in other forums is permitted, provided the original author(s) or licensor are credited and that the original publication in this journal is cited, in accordance with accepted academic practice. No use, distribution or reproduction is permitted which does not comply with these terms. 